\title{
Musical Communities: Rethinking the Collective in Music
}

\section{Citation}

Shelemay, Kay Kaufman. 2011. Musical communities: rethinking the collective in music. Journal of the American Musicological Society 64(2): 349-390.

\section{Published Version}

doi:10.1525/jams.2011.64.2.349

\section{Permanent link}

http://nrs.harvard.edu/urn-3:HUL.InstRepos:8810547

\section{Terms of Use}

This article was downloaded from Harvard University's DASH repository, and is made available under the terms and conditions applicable to Open Access Policy Articles, as set forth at http:// nrs.harvard.edu/urn-3:HUL.InstRepos:dash.current.terms-of-use\#OAP

\section{Share Your Story}

The Harvard community has made this article openly available.

Please share how this access benefits you. Submit a story.

Accessibility 
$\partial$ (ital.) throughout

$\partial$ (roman) throughout

$\varnothing$ in Works cited, under Swinehart

$<\mathrm{ct}>$ Musical Communities: Rethinking the Collective in Music $<\mathrm{ca}>$ KAY KAUFMAN SHELEMAY

$<$ epi $>$ 'Tis but thy name that is my enemy ... What's in a name?

$<$ episig > - Shakespeare, Romeo and Juliet

$<\mathrm{fl}>$ "Community" has attained a status across the disciplines as a "keyword," a term that "organizes knowledge" in powerful ways. ${ }^{1}$ The word is so widely used that it may be invoked repeatedly in one context without definition or be summarily discarded in another. ${ }^{2}$ This is indeed the case in broader musicology, where the study of collectivities has long been at the center of research, but where there have been few critical discussions of the ways in which musicologists employ the term "community," or why some have chosen to discard it or to replace it with alternative expressions. This essay explores the complicated intellectual history of the term "community" in the study of musical collectivities, and suggests a revised approach based in part on research among recent immigrants to the U.S. forced by circumstance to establish their social and musical lives anew. ${ }^{3}$

$<$ txt $>$ Rethinking the notion of community opens opportunities first and foremost to explore musical transmission and performance not just as expressions or symbols of a given social grouping, but as an integral part of processes that can at different moments help generate, shape, and sustain new collectivities. This discussion therefore seeks both to reappraise community studies in musical scholarship and to shift the focus to music's role in community formation.

I will suggest that more nuanced attention to discourse about community by music scholars could enhance broader musicology's own approaches to this subject, while opening opportunities to contribute to multiple areas of cross-disciplinary interest, ranging from the lively field of boundary studies in sociology to studies of the impact of music on social bonding now emerging from neuroscience. While the quotation reproduced above from act 2, scene 1 of 
Shakespeare's Romeo and Juliet summarizes in an ironic way the central issue at stake here, I am in fact not persuaded that "That which we call a rose / By any other word would smell as sweet." In a world where academic discourse is often impenetrable to those outside scholarly circles, the term "community" provides an opportunity both to have a conversation that does not require translation, and to bring together the perspectives of research associates with the scholar's efforts at interpretation. Instead of casting about for nominal alternatives to the word "community," it is worthwhile to try to redefine and deepen approaches to this term. Given the challenges of the subject, a thicket of terminological issues can obscure an already complex situation in which "the subject is not simply what you start with, as an origin, nor where you end, as a closure."4

The first section of this article will explore the use of the term "community" and identify factors that have shaped its receding role in pockets of present-day musical scholarship. ${ }^{5}$ The second section will summarize conventional definitions and the search for new nomenclature that has provoked the most lively discussions of this subject to date. In the third, I provide my own working definition and suggest a new framework that seeks to re-claim "community" as an explicit subject of musical scholarship, and as part of an updated search to define music's generative role in social processes with very different outcomes. The final, fourth section sets forth points of possible intersection with scholarship in the social sciences and sciences and raises questions that could lead to broader conversations on a subject quite central to musical scholarship that tends to be relegated to the background. ${ }^{6}$

In section three, I will draw on case studies from my research in domains of Ethiopian diaspora music that have realigned my approach to music's generative role in the formation of clearly differentiated social groupings. ${ }^{7}$ It is here that I incorporate insider perspectives that speak to the role of musical processes in social bonding and their collective outcomes. Since the advent of the Ethiopian revolution in 1974, as well as following on a spate of natural disasters and various regional conflicts, millions of people have departed from Ethiopia and adjacent regions in the Horn of Africa. They have resettled in a diaspora that is today truly global, with the largest single cluster located in the Washington, D.C., metropolitan area. ${ }^{8}$ Beyond the sheer number of musicians forced to migrate, particularly notable is their prominent role in both sustaining social ties and in galvanizing new collectivities during the processes of migration and resettlement. ${ }^{9}$ But I found that I lacked a critical framework for approaching the collective in ways that could accommodate the plethora of musical styles as well as the complex processes of 
change and displacement underway. Music, at once portable, malleable, and available for easy reproduction in contexts where material resources are at a premium, is deeply implicated in multiple domains of Ethiopian immigrant and refugee experience. During 2007-2008, I tracked individual musicians who performed the widest range of Ethiopian musical styles, seeking to map their views of their own positions in new environments and to construct an overview of musical heterogeneity and its social outcomes. The case studies discussed in this article emerge both from this recent round of focused exploration and from my longer-term studies of the Ethiopian homeland and the formation of its diaspora. I will also refer to other case studies as they seem relevant and shed light on important points. Together these materials provide considerable grist for rethinking collectivities as generated through and by musical initiatives within what might have been conventionally conceived as a single community. But before considering the materials that sparked this inquiry, we must first survey the notion of community in present-day musical scholarship and the subtle, if protracted, debate over the term itself.

\section{$<$ A $>$ I. Musical Scholarship and the Search for the Collective}

$<\mathrm{fl}>$ In a presentation at the fiftieth anniversary meeting of the Society of Ethnomusicology, Bonnie Wade noted that " . . . an overweening focus on communities" had given way by the early twenty-first century to "a somewhat better balance in our focus between 'culture' with shared values in the sense of communities and the individual." ${ }^{10}$ Thomas Turino has charted a shift to defining the ethnomusicological subject as "ongoing dialectical interactions between individuals and their social and physical surroundings realized through observable practices," and has suggested that "any general theories about artistic processes and expressive cultural practices would do well to begin with a conception of the self and individual identity, because it is in living, breathing individuals that 'culture' and musical meaning ultimately reside."11

$<$ txt $>$ From early on, ethnomusicologists sought to situate musical transmission and performance within a broader context of shared cultural behavior and values. Communities united by ethnic, religious, regional, or national ties provided primary data for ethnomusicological research until the present, whether that inquiry was driven by shifting intentions over time to describe, salvage, or theorize their subject matter. Large, participatory groups such as Ghanaian drumming ensembles and Indonesian gamelans attained prominent 
places in the ethnomusicological canon at least in part because of scholarly and popular interest in the close social relationships they generate through acts of performance. ${ }^{12}$ However, the advent of popular music studies by the 1990s (as well as other broader disciplinary trends to be discussed below) was part of an important paradigm shift that propelled ethnomusicological research away from a focus on geographically fixed communities. Attention moved decisively to appraise musical ties stretching across geographical boundaries, often those transmitted through new technologies. ${ }^{13}$ Meanwhile, the study of formerly local communities focused on their displacement and subsequent musical lives in transnational diaspora settings. ${ }^{14}$ Despite this shift, however, the broadly social nature of ethnomusicological subject matter and exploration remained deeply relevant and very much in view. Yet while attention to collectivities has been a defining characteristic of cross-cultural music scholarship, ethnomusicologists have by no means had a monopoly on community studies.

In historical musicology, the longtime engagement with individual composers, performers, and repertories shifted decisively in the second half of the twentieth century toward increasingly broader contexts, whether they were the geographic, cultural, religious, national, or political settings of which music is so integral a part. Studies of music within European aristocracy and courts, churches, and urban centers proliferated while musicologists also gave growing attention to musical collectivities linked by diacritica such as gender and, more recently, age cohorts. ${ }^{15}$ Here one might observe that the music subdisciplines have to a certain extent converged in recent decades, with music historians moving emphatically into collective cultural domains while ethnomusicologists have begun to embrace the study of the individual. ${ }^{16}$

Musicological attention to the presence of multiple and diverse musical communities has been especially prominent in the work of scholars of American music who were from early on sensitive to cultural pluralism and its manifestations in American musical life. Gilbert Chase's classic volume, America's Music, highlighted a concern with musical and social processes, moving away from a focus on historical epochs and musical genres to devote chapters to a wide array of collectivities ranging from musical puritans to gentlemen amateurs. ${ }^{17}$ Chase's approach embraced both the individual and the collective, growing out of his conviction that " . . the American musical landscape . . . could be resolved into no distinct pattern. Rather, it was an arena in which a vast congeries of individuals and groups had made music according to their own needs and musical tastes ..."18 A number of studies concerned with American musical diversity 
followed on Chase's example, providing varying perspectives on American music over time with particularly close attention to musical enactment of ethnic identity. ${ }^{19}$

In sum, music historians have for decades given close attention to collectivities of all types, with particular attention early on in European studies to the music associated with and promulgated by ruling elites. Concern with vernacular musical practices of communities united by ethnic identity emerged most markedly in Americanist musical scholarship of the second half of the twentieth century and began late in the century to overlap and interact both in subject matter and in ethnographic methodologies with ethnomusicological studies.

That most aspects of the musical experience cannot be studied without considering different modalities of collective experience, and that the literature is permeated with case studies of collectivities past and present, renders even more striking the dearth of critical discussions about concepts of community in musical scholarship. ${ }^{20}$ For instance, a prominent volume featuring a dozen case studies of North American musical communities does not set forth a definition of a musical community. ${ }^{21}$ There are a few recent contributions to the ethnographic discussion of community in the literature, such as a case study of the construction of a new musical community through ensemble performance activity at a California university, an exploration of a musical community on the internet, and a volume of essays that explicitly approaches cultural rights as defined and protected as part of a community, with emphasis moving "from individual rights to collective or group rights." 22

Of singular importance in its theoretical contribution to the subject of community, however, is Thomas Turino's monograph cited above, Music as Social Life: The Politics of Participation. After providing a definition of culture as "the habits of thought and practice that are shared among individuals," Turino goes on to distinguish and define two main types of social groupings: “ . . I I discuss different ways that shared habits bind people into social groups according to specific aspects of the self (gender, class, age, occupation, interests, etc.), what I call cultural cohorts, as well as the broader more pervasive patterns of shared habits that give rise to cultural formations." 23

While Turino includes historical case studies regarding the generative role of music in the formation of collectivities, notably during the Third Reich in Germany and in the American folk music movement, his interests focus more directly on the meanings of musical performance as conveyed and experienced through presentation, participation, or technological mediation. ${ }^{24}$ 
Turino does not dwell on the concept of "community" and the challenges of definition, although he emphasizes throughout that "music, dance, festivals, and other public expressive cultural practices are a primary way that people articulate the collective identities that are fundamental to forming and sustaining social groups, which are, in turn, basic to survival. ${ }^{25}$ Similarly, one finds commentary about musical communities scattered in other sources, such as a classic musicological overview of the process of boundary formation as musical communities define themselves over time; an exploration of the musical processes that sustain tribal survival as Native American communities adopt and adapt in contexts of exchange and interaction; and a study of underground dance that discusses the interaction of African American and gay subcultures in New York City's post-disco culture as two interacting communities. ${ }^{26}$

$<\mathrm{A}>$ II. Reconsidering Definitions and Terminology: What Is a Musical Community?

$<\mathrm{fl}>$ The word community, derived from Latin, has been in use in English since the fourteenth century, but did not acquire present-day local associations until the twentieth century. ${ }^{27}$ The Oxford English Dictionary defines community first and foremost as a collectivity, that is, "a body of people or things viewed collectively." ${ }^{28}$ It is a subsequent part of the $O E D$ definition (2b) that links a group to a single geographic setting, as "a body of people who live in the same place, usually sharing a common cultural or ethnic identity. Hence: a place where a particular body of people lives." 29

$<\mathrm{txt}>$ The notion that a community is localized has cast doubt for some as to the utility of the word in an era of increasingly mobile and cosmopolitan populations. ${ }^{30}$ The history of community studies is a massive field well beyond the purview of this article, but a very brief overview can provide a general backdrop for better understanding the emergence of community studies across disciplinary boundaries, such as those of sociology and anthropology, that have interacted with and, in some cases, shaped the treatment of community in musical scholarship.

The genesis of the study of community is generally dated to the work of the German sociologist Ferdinand Tönnies (1855-1936), who theorized a distinction between Gemeinschaft (a community based on individual social relationships) and Gesellschaft (civil society). ${ }^{31}$ The inception of community studies in the U.S. is often dated to sociological work of the late 1930s, which soon joined with urban studies at the University of Chicago to produce a series of classic 
publications that shifted the focus from entire towns to smaller subsets in urban areas and theorized their study. ${ }^{32}$ By the second half of the twentieth century, interests moved to exploring communities as sites of identity, with particular attention to ethnicity. ${ }^{33} \mathrm{~A}$ landmark study by Adelaida Reyes Schramm led musical scholarship into North American urban areas, looked closely at ethnic identity, and considered the construction of both formally and informally constituted performing groups. ${ }^{34}$ That the subject of ethnic communities remains a lively (and disputed) subject is made clear by stimulating studies that problematize the term "community" in new and creative ways, such as a study of a "phonic community," including studying ethnic differences through analyzing "the sound of the community" and the ways in which community members "come to 'recognize' each other" through noise-creating voices. ${ }^{35}$

$<\mathrm{B}>$ Concepts of "community" in a changing intellectual landscape

$<\mathrm{fl}>$ While sociologists continue to write about communities and to follow up especially on Fredrik Barth's work in generating a lively theoretical literature regarding boundary formation, discussions of single-locale communities began to recede in musical scholarship by $1990 .{ }^{36} \mathrm{I}$ suggest that we can ascribe this sharp turn away from community studies to the cumulative impact on humanistic scholarship of several pivotal works dating to the prior decade. ${ }^{37}$

$<\mathrm{txt}>$ The first was Benedict Anderson's Imagined Communities, which sought to define an elusive complex of terms - nation, nationality, nationalism - as "cultural artifacts of a particular kind." ${ }^{38}$ Anderson, a scholar of Indonesian political history, proposed that

$<\operatorname{ext}>[$ The nation] is an imagined political community — and imagined as both inherently limited and sovereign ... In fact, all communities larger than primordial villages of faceto-face contact (and perhaps even these) are imagined. Communities are to be distinguished, not by their falsity/genuineness, but by the style in which they are imagined ... [The nation] is imagined as a community, because, regardless of actual inequality and exploitation that may prevail in each, the nation is always conceived as a deep, horizontal comradeship. ${ }^{39}$ 
$<$ txt $>$ Anderson's suggestion that all communities, even local ones, may be imagined has had a continued prominence in ethnomusicology well beyond his own area specialization of Southeast Asian studies; it has also resonated among music historians. ${ }^{40}$

A second transformative work appeared two year after Anderson's monograph: Anthony P. Cohen's The Symbolic Construction of Community, which proposes understanding community not as a structure to be defined and described, but as a mode of experience that has meaning to people who consider themselves to be part of it. ${ }^{41}$ According to Cohen, a community is "a matter of feeling, a matter which resides in the minds of the members themselves" and is based on sharing of particular symbols, such as ritual orders or, for our purposes, musical performance. ${ }^{42}$ In this way, Cohen disputed one of the key concepts of the social sciences, the notion of a community as fixed in time and place, and described it instead as "a largely mental construct, whose 'objective' manifestations in locality or ethnicity give it credibility.",43

If Cohen's notion of community construction emerges from the crucible of symbolic anthropology, it is a close relative to political scientist Anderson's notion of imagined communities. Both studies align also with historical work that appeared around the same time in the early 1980s, notably Eric Hobsbawm and Terence Ranger's edited volume, The Invention of Tradition. ${ }^{44}$ Hobsbawm suggested that, in the wake of the industrial revolution, many things that appeared to be ancient and linked to immemorial past - from the kilts of Highland Scotland to military practices imposed on colonial Africa—were in actuality products of recent times. Thus an invented tradition is

$<$ ext $>$ taken to mean a set of practices, normally governed by overtly or tacitly accepted rules and of a ritual or symbolic nature, which seek to inculcate certain values and norms of behaviour by repetition, which automatically implies continuity with the past. In fact, where possible, they normally attempt to establish continuity with a suitable historical past ... It is the contrast between the constant change and innovation of the modern world and the attempt to structure at least some parts of social life within it as unchanging and invariant, that makes the "invention of tradition" so interesting for historian of the past two centuries. $^{45}$ 
$<$ txt $>$ These three powerful sources destabilized notions about the genesis, history, and structure of communities at all levels and pushed ethnomusicologists in particular to reassess the community as a unit of study. By the later 1980s, publications from anthropology and cultural studies began to focus on patterns of mobility that characterized the second half of the twentieth century and would eventually provide additional new models for studying routes instead of roots. ${ }^{46}$ Cultural geographers contributed their own creative readings of urban spaces, remapping them as intersecting and overlapping topologies called "thirdspace," encouraging the reader to "think differently about the meanings and significance of space and those related concepts that compose and comprise the inherent spatiality of human life: place, location, locality, landscape, environment, home, region, territory, and geography." ${ }^{47}$ The notion of community had, on all levels from the local to the global, been substantially retheorized and remapped.

\section{$<1 \mathrm{~s}>$}

$<\mathrm{fl}>$ Thus the concept of community shifted radically from "the sense of immediacy or locality ... in the context of larger and more complex industrial societies." 48 At the same time, the term "community" continued to be "used so pervasively that it would appear to be nearly meaningless." 49 Thus "community" has been frozen at the juncture of competing theories of location, mobility, identity, and politics, becoming in the process so ambiguous that to use the term is to be confronted with the necessity to argue for its use. This situation has left music scholars struggling for new ways to name and theorize about the collective in music. As a result, a number of scholars in music, as well as those engaged with music in related disciplines, have pushed the term "community" to the margins and have explored a range of alternative terms and concepts, including subculture; art worlds and musical pathways; and the music scene.

\section{$<$ B $>$ Alternative terms}

$<\mathrm{C}>$ Subculture. Influenced by his training at the Birmingham Centre for Contemporary Cultural Studies, Dick Hebdige utilized the notion "subculture" to apply to a group of youth, generally in opposition to a larger mainstream, defined by their shared, clearly marked, and often disputed styles of dress, behavioral conventions, and language usage. ${ }^{50}$ Hebdige analyzes punk subculture as emerging through a process during which objects or practices are rendered meaningful and are reinterpreted as the defining style of the collectivity; one could fruitfully apply this explanation 
to music's role in shaping subculture, which of course is an explicit aspect of the punk culture explored in Hebdige's monograph. A concern with subculture, and a special commitment to the study of subaltern communities, has in many ways held a place of privilege in ethnomusicological studies of musical groups. However, ethnomusicologists have tended to focus more on the lived social reality of subculture - documenting and interpreting the role of musical performance within such groups - and rather less on the musical processes that may have contributed to the rise of the cohort per se.

$<\mathrm{txt}>$ Among the notable applications of subcultural theory in musical scholarship is Mark Slobin's Subcultural Musical Sounds: Micromusics of the West. ${ }^{51}$ Slobin drew on Hebdige's theories to make sense of increasingly complex Euro-American musical worlds and to take account of their multiple subgroupings (micromusics, in his terminology) from a comparative perspective. Slobin's subjects were subcultures established as people and their musics were in transit across international boundaries and flowed through global electronic networks. Slobin proposed a tripartite framework for studying "the big picture" that moved top down from superculture to subculture, and interpolated an interactive layer in between that he termed "interculture." Slobin's most sustained attention to collective identity is a discussion of ensembles in chapter 6 of his book, providing only brief discussions to individual communities within his fluid, multi-level framework. ${ }^{52}$

$<\mathrm{ls}>$

$<\mathrm{C}>$ Art worlds and Musical pathways. Other new nomenclature came from sociology, the discipline that has led the way in community studies since its inception. Notable among the sociological literature on communities is Howard S. Becker's Art Worlds, which provides a theoretical framework for understanding art as a social product. ${ }^{53}$ Becker documents the forms of ephemeral cooperation that produce artistic outcomes, which themselves become routine over time. If his work is of great interest because of its attention to the social interactions that give rise to expressive activity —one of his most cogent examples is the processes that shape the workings of the symphony orchestra- his end point is understanding the production of art, not the generation of communities through this process. Perhaps because Becker's art world is quite Western in its orientation, separating art's "inspiration" from a rather functionalist view of the "support activities" that shape it, it has not had much resonance within cross-cultural musical scholarship to date. ${ }^{54}$ 
$<$ txt $>$ An exception is Becker's acknowledged impact on Ruth Finnegan's The Hidden Musicians, which surveys “musical worlds" in Finnegan's English hometown of Milton Keynes. ${ }^{55}$ Finnegan rejects the term "community" as too closed, integrated, and concrete to capture nuance of local musical collectivities; she is more receptive to "groups," but thinks this word does not capture connections adequately either. ${ }^{56}$ Inspired by network theory, Finnegan cites but declines to inflect Becker's rubric to "musical worlds," choosing to approach the diverse domains of urban music making through the use of the metaphor "musical pathway." Finnegan writes that through this phrase she intends to capture regular musical activities which people chose or were led into, and which they kept open and extended through their actions. ${ }^{57}$ The concept of "musical pathway" is at once intended to convey the notion of networks or groups, but to "avoid the misleading overtones of concreteness, stability, boundedness, and comprehensiveness associated with the term 'world.' "58 Finnegan does offer a brief and quite local definition of community, which she glosses "as people . . bounded by numerous ties, [who] know each other, and have some consciousness of personal involvement in the locality of which they feel part." ${ }^{, 59}$ She also includes a long footnote with references to discussions of community, but in the end rejects the term as not fitting the musical practices she studied, for many of the same reasons she does not use the phrase "art worlds." ${ }^{\circ 0}$ Finnegan's "musical pathways" has not been widely invoked in the ethnomusicological literature, probably because "there is little comfort in the term . . . since it does not explain, but merely describes, the problem. ${ }^{61}$ While Finnegan's "musical pathways" captures a sense of process and simultaneity absent from domains of subculture and art worlds, the framework remains quite linear. It is perhaps best suited for comparative work in a single locale like Finnegan's field site, the English town of Milton Keynes, where multiple musical trajectories intersect and overlap.

\section{$<\mathrm{ls}>$}

$<\mathrm{C}>$ The music scene. The most widely circulated rubric used in lieu of community is the "music scene." Drawing on the work of Edward Said, as well as the notion of scene as advanced by Barry Shanks, Will Straw has defined a musical scene as "that cultural space in which a range of musical practices coexist, interacting with each other within a variety of processes of differentiation, and according to widely varying trajectories of change and cross-fertilization."62 Straw finds the term "community" too heavily associated with concepts of space and nation and 
finds it "problematic in popular music where disruption and fragmentation of cultural communities has often masked . . the investment in imaginary unities which underlies it. ${ }^{63}$

$<\mathrm{txt}>$ In the sociological literature, scene is discussed as a substitute rubric for community in attempting to explain "the significance of music in everyday life." ${ }^{64}$ While scene is indeed used as an alternative and counterweight to the concept of a community constituted of people living in and involved in local music making, at the same time "scene" sustains the secondary notion of community by describing an ideology of bonding expressed through music, generating a shared sense of belonging. ${ }^{65}$ Since his original publication, Straw has further noted that scene "functions to designate face-to-face sociability and as a lazy synonym for globalized virtual communities of taste."

Scene has proven to be a very generative framework in the field of popular music studies in particular, which focuses on fast-emerging musical trends circulated through global networks and across boundaries of widely dispersed cultural groupings. The flexibility of "scene" makes room for musical groups that arise through different processes and for which "community" is not considered flexible enough to capture without modification. The use of scene as a rubric seeks to reconcile two countervailing pressures:

$<$ ext $>\ldots$ One towards the stabilization of local historical continuities, and another which works to disrupt such continuities, to cosmopolitanize and relativize them.... The point is not that of designating particular cultural spaces as one or the other, but of examining the ways in which particular musical practices "work" to produce a sense of community within the conditions of metropolitan music scenes. ${ }^{67}$

$<\mathrm{fl}>$ However comfortably the scene framework accommodates inquiry about widely dispersed music trends and the processes that shape collectivities that receive them, and although Straw endeavors to include "temporal and spatial density," the evanescent materials in the popular realm provide little incentive to delve into their historical genealogies. ${ }^{68}$ The etymology of the word "scene," from the Latin scena and ultimately, from the Greek skene (tent, stage) resonates with approaches by Anderson and Hobsbawm discussed above, which focus on the construction of entities ranging from subcultures to nations through processes of invention or imagination. ${ }^{69}$ By suspending inquiry in an abstract space, the scene framework risks neglecting cultural and 
historical aspects; the common use of scene as a frame for a transitory event or generative moment is also quite tricky to deepen. The focus on the ideological affects of music - its ability to catalyze "musical alliances" and to redraw social boundaries-are, however, quite relevant to a study of the ways in which musical activity works to generate collectivities. ${ }^{70}$ But here Mark Slobin's tripartite framework tracking music's path through the interaction among subculture, superculture, and interculture offers equally multilayered and nuanced inquiry. ${ }^{71}$

$<\mathrm{txt}>$ At this point, then, we arrive at an impasse. Clearly, music and its performance serve to catalyze and subsequently define different groups of people in different ways, whether to bring groups together or to reaffirm the boundaries that divide them. But these social outcomes of musical performance do not differ simply on the basis of locality, nor can they be easily mapped, even in multiple dimensions, on specific musical styles. At the same time, music has certainly been used in the service of all varieties of the social imagination. Music often impels the formation of collectivities by the strength of its ability to communicate to listeners. It carries emotional meaning and establishes what have been termed "audible entanglements," rendering "audible and visible specific constituencies, and imaginations of longing, belonging, and exclusion." 72

By acknowledging music's integral role in social processes, one can move toward a framework that seeks both to define the attachments evoked through musical performance, and to frame dimensions of collective affiliation that are its outcomes. At this point, I will return to the concept of "community" with some new proposals, recognizing that some might at this point be ready to conclude that

$<$ ext $>$ Community is so fundamental a concept, encompassing as it does myriad ways of thinking and talking about human collectivities, that it quite unsurprisingly is a term which is impossible to define with any precision. Indeed, there are good reasons why such definition should be avoided, chief among them being the large body of comparative ethnographic evidence which shows communities to be imagined, constructed and reconstructed in ongoing human relations, sometimes consensual, sometimes contentious. ... As such, it is a term best understood in action. . . . ${ }^{73}$ 
$<\mathrm{txt}>$ Indeed, community is a term that needs to be approached "in action," and below I take an ethnographic approach to a specific community, that of Ethiopian immigrants to the United States, in order to explore the conjunction of concepts of community with musical concepts and performance. Through this method, I will draw on insider notions to cut through the scholarly terminological dilemma and to suggest a more nuanced approach.

\section{$<$ A $>$ III. Rethinking and Expanding on "Musical Community"}

$<\mathrm{fl}>$ To begin, I will compare notions of "community" based on my reading of Western scholarly sources with those from the Ethiopian social and musical practices. Building on the scholarly literature cited above, I offer the following definition of "musical community":

$<$ ext $>$ A musical community is, whatever its location in time or space, a collectivity constructed through and sustained by musical processes and/or performances. A musical community can be socially and/or symbolically constituted; music making may give rise to real-time social relationships or may exist most fully in the realm of a virtual setting or in the imagination.

A musical community does not require the presence of conventional structural elements nor must it be anchored in a single place, although both structural and local elements may assume importance at points in the process of community formation as well as in its on-going existence. Rather, a musical community is a social entity, an outcome of a combination of social and musical processes, rendering those who participate in making or listening to music aware of a connection among themselves."74

$<$ txt $>$ To turn to the Ethiopian cultural domain, there are several words that convey notions of "community.",75 The first, mändär, (lit., "village") conveys a strong sense of local collectivities, ranging from a village, to a hamlet, to a neighborhood in a city. One form of the word's root, mänädäri, conveys agency of the one who founds a village, while another, ammänädadär, refers to the process and manner of building or founding a community. ${ }^{76}$ 
A second word, $h \partial z b$, conveys a sense of community or people in a secular or popular sense, without an attachment to a locality. This term can be modified to signify an ethnic, religious, or civil community, ranging from the nation to a mob. ${ }^{77}$

The third term is kominiti, a loan word from English, most often used to refer to collectivities such as European or other foreign groups (communities) living in Ethiopia.

In seeking an Amharic phrase that is equivalent to the English concept of "musical community," the expression yämusiqa gwadd, glossed as "orchestra," appears to be the closest. Here the borrowed term musiqa is used to modify the noun gwadd, which generally refers to a collectivity such as a team. $^{78}$

To summarize, one finds terms for community in common use in Ethiopia, reflecting both local and symbolic uses of the term familiar from Western parlance. Most interesting is the use of a version of the English word "community" well before the revolution and diaspora exposure abroad, documenting the term's cross-cultural dispersion. While the concept of ethnic group is a familiar one in Ethiopia, and there are frequent references to distinctive ethnic cultural traditions, including music, there is only occasionally discourse on "musical communities" per se. $^{79}$

Comparing Western and Ethiopian concepts of "community" in conjunction with music and musicians is also rendered somewhat more complex by its intersection of notions of community with a taxonomy of music long established in highland Ethiopia. Distinctions are made first and foremost between sacred (zema) and secular (zäfän) styles and repertories. ${ }^{80}$ Secular styles then break down into two broad categories, each with its own internal complexities: bahdlawi (lit., "cultural music"), referring to traditional, secular musical styles associated with ethnic or regional communities; and zämänawi (lit., "timely"), referring to modern or popular music, including international styles such as jazz and hip-hop new to the Ethiopian experience in the twentieth century. These distinctions are quite actively used in the Ethiopian diaspora, as a Washington, D.C., concert celebrating the Ethiopian Millennium in 2007 dramatically illustrated. The performance was formally divided into three parts, the first featuring a group of church musicians performing zema, the second, presenting a group of traditional musicians performing baholawi music from multiple ethnic groups on indigenous instruments; and the third, featuring a big band performing jazz and other zemänawi music. ${ }^{81}$ 
The Ethiopian materials thus set forth concepts of community which can be wedded to different musical styles. The union of social and musical domains gives rise to an array of different collectivities. In the words of one Ethiopian musician interviewed:

$<$ ext $>$ Music has a strong role within the Ethiopian youth community, or in the general community. Ethiopians have always explained their anger, pride, problems, and love of country through music. . . . At the same time, music in Ethiopia, as anywhere else, it is very special. It brings people together for common purpose, for national purpose, for religious purpose, for anything you like. ${ }^{82}$

$<$ txt $>$ In sum, no single musical style correlates to a particular community type. Rather, as illustrated by the concert celebrating the Ethiopian Millennium, a desire to address multiple religious, political, ethnic, and age cohorts at that event necessitated a very heterogeneous array of musical choices. This event, and others I have observed over the course of extended fieldwork, as well as the testimony of research associates, suggests that a closer look at social/musical processes and different social outcomes might provide a promising way to proceed.

Below I set forth a tripartite framework that seeks to unite the social and musical domains, and in so doing, to accommodate the widest range of musical styles. I will discuss processes of descent, dissent, and affinity as expressed through music and the collectivities they generate. $^{83}$

\section{$<\mathrm{B}>$ Processes of descent}

$<\mathrm{fl}>$ We begin with descent, a broad category under which are subsumed a number of social processes that generate collective identity. ${ }^{84}$ Processes of descent give rise to what I will call "descent communities" united through what are understood from within to be shared identities, whether they are grounded in historical fact, are newly invented, or emerge from some combination of historical circumstance and creative transformation. Processes of descent have long dominated traditional discussions of community, not the least because there are in fact numerous aspects of identity that fall under the rubric of descent. To name just a few, there are 
collectivities generated by shared ethnicity or aspects of kinship, with religious and/or national ties constituting other significant descent categories. Often, two or more of these designations converge and overlap: for instance, ethnic communities often emerge from processes informed both by biological kinship and religious practices. In the (increasingly distant) past, many, if not most, descent communities were associated with a particular locale or region. Descent communities were generally the collectivities that attracted music scholars to the notion of community in the first place. The longtime use of "community" as an equivalent to one of many modalities of descent eventually spelled the end of the utility of the term, for migration unsettled geographical fixity and changing technologies opened new channels of mobility and symbolic community construction.

$<$ txt $>$ Within collectivities shaped by processes of descent, music moves beyond a role as symbol literally to perform the identity in question and serves early on in the process of community formation to establish, maintain, and reinforce that collective identity. I suspect that most music historians and ethnomusicologists would be willing to argue that descent communities would have been unable to sustain themselves over time were it not for these musical practices. The processes through which these communities arise and sustain themselves very often occur through the catalyzing impact of musical performance. Music helps generate and sustain the collective, while at the same time, it contributes to establishing social boundaries both within the group and with those outside of it. Music can also provide avenues to penetrate these social boundaries and to bring new constituencies into the fold. But processes of community formation are not unitary and can vary both between collectivities and within the same collectivity over the course of time. To acknowledge these possibilities is highly significant for ethnographic work, as well as vital for a nuanced historical perspective of events over the course of time.

Let me turn for an example to a brief discussion of the collectivity surrounding Ethiopian Orthodox Christianity, an Ethiopian community grounded historically in religious identity and within which music has played a pivotal role. This is a community of remarkable longevity, dating from the conversion of the Ethiopian court by Syriac missionaries in the early fourth century. ${ }^{85}$ A central origin myth of the Ethiopian Christian community, enshrined in church writings, iconography, and oral tradition, is the importance of liturgical chant performance to the Ethiopian Orthodox community: "It is often said that to understand the ethos of the Ethiopian 
Orthodox Church it is necessary to participate in its worship. At the core of this worship is the Mahelet ("lit. hymns and sacred songs"). . . " 86

Chant, sacred instruments, and dance constituted vital aspects of Ethiopian Christian liturgical practice from the earliest dates for which we have evidence and certainly established clear boundaries early on between Christians and other religious communities in Ethiopia as well as between Ethiopia and the Christian world beyond its borders. At the center of the narrative of Ethiopian church history rests the myth of a charismatic musician, Saint Yared, believed by the faithful to have received the entire corpus of Ethiopian chant through divine inspiration. That Saint Yared is traditionally said to have lived during the reign of the sixth-century Emperor thought to have unified and consolidated Christian liturgical practice speaks to the generative role music is believed to have played in the establishment of Christian ritual and in establishing a worship community. ${ }^{87}$ Thus musical performance of rituals gives voice to beliefs that unite the congregation, reenacts the story of St. Yared through its recreation by his musical heirs, and at the same time reinforces social hierarchies within the church and, until the 1974 revolution, in Ethiopian society at large. Music also served to demark boundaries within the Church, both between different groups of the clergy and between the clergy and the laity. ${ }^{88}$

The chant tradition transmitted for centuries in the Ethiopian Orthodox Christian Church both provided the backbone for ritual orders and engendered a sense of belonging. Over time, it is clear, the identity of this religious community melded with other aspects of descent. The Ethiopian Christian community came to have strong associations with particular ethnic groups (particularly the Amhara and Tigray peoples of the Ethiopian highlands, regions where the church was initially established) and accrued strong national, political, and class associations due to centuries of leadership by Orthodox Christian emperors who both ruled Ethiopia and headed the church. ${ }^{89}$ This case study suggests that there are different types of descent communities and that any given descent community can, at a particular point in time, become associated with additional streams of descent.

Ethiopian Christian sacred music helped shape community formation and maintenance through much of the history of the Ethiopian church, including following the overthrow of the monarchy by a military coup in 1974. During the violent revolutionary years that followed, music provided one of the few areas of continuity amidst a range of economic and structural changes. ${ }^{90}$ 
As the Ethiopian military leaders displaced the lineage of Christian Amhara monarchs who led the Church, they sparked a long political crisis that led to the forced migration of hundreds of thousands of Ethiopian Orthodox Christians abroad. What had been a national church with deep political and economic resources became a religious heritage carried by an ethnic/religious community that had forfeited political and economic power within its homeland and was now constituted of struggling refugees abroad. During this period of trauma, music proved a flexible framework, both maintaining continuity and absorbing changes.

At the same time as the identity of an Ethiopian Orthodox Christian refugee community linked by descent was arguably heightened in some ways by forced migration, other social processes quickly came into play as well. The rupture in Ethiopian Church history at the moment of the 1974 revolution and the changing role of music within it provides a transition to my second category, which focuses on processes of dissent and the collectivities that emerge during heightened moments of conflict.

\section{$<\mathrm{B}>$ Processes of dissent}

$<$ fl $>$ If a descent community claims a primordial connection, whether based on historical factors or invention, dissent catalyzes a decidedly different process of community construction, one based solidly in opposition. While dissent communities often emerge from minority groups or from those considered to hold subaltern status within a larger society, dissent may not always be formulated in opposition to a dominant majority. However, dissent communities do generally emerge through acts of resistance against an existing collectivity; dissent communities also tend to coalesce quite rapidly, arising in response a particular event or circumstance at a specific moment in time. Individuals involved in processes of dissent quite regularly draw on musical performance as a mechanism to enlist others in their cause. Indeed, many dissent communities emerge through music making in part because music can give voice to dissent while partially masking its critical edge and reducing risks of retribution from more powerful forces. To take a well-known example, the American folk music revival, which emerged in the U.S. during the late 1950s and 1960s, provides a prototypical example of a countercultural dissent community whose message was initially conveyed through music, with a growing following - a newfound community — produced by widespread circulation and performance of memorable songs. ${ }^{91}$ 
$<$ txt $>$ But we can also return here to the case study of Ethiopian Orthodox Christian music, in order to see how the performance of the chant tradition and the rituals associated with it shifted from a straightforward affirmation of belief closely associated with descent to a channel for political resistance and dissent. Performance of the Ethiopian Christian ritual and its musical content became an important force in reconstituting a fractured community as an integrated whole in distant homelands. ${ }^{92}$ But the Ethiopian Christian liturgy performed in exile also signaled, for many participants, dissent against changes in the homeland and provided weekly commemorations of the dismantling of their historic church. ${ }^{93}$ At the same time, liturgical music and its performance draw the immigrants together and establish new boundaries around and within this refugee community. A community of descent has been, at least in part, reconstituted as a community of dissent.

Other changes within Ethiopian Christian musical life and related worship practices also serve to express dissent against well-established traditions from the past. In the years immediately before the revolution began in 1974, a new tradition of choral singing with vernacular Amharic language texts emerged in the Ethiopian church. ${ }^{94}$ Choirs constituted of young people became very widespread by the 1980s, in part because they provided a social context in which groups, otherwise forbidden, could convene during the Ethiopian revolution. By the end of the revolution in 1991, the choirs were well established in urban Ethiopian churches and also spread quickly throughout its growing diaspora. While the traditional liturgy in Ge'ez, along with its dance and instrumental practice was historically performed only by male musicians, the new choirs singing Amharic-language strophic hymns were dominated by women, who simultaneously began to play increasingly active roles in diaspora religious life. The new choirs, actively resisted by many priests and däbtära because of their departure from tradition, were a first step in forging a new community in diaspora, which included women performing with sistra, drums, and prayer staffs formerly restricted only to men. In the case of Ethiopian Orthodox Christianity, then, a full measure of dissent against traditional gender roles in the church was pursued and institutionalized through musical performance. Thus dissent can be seen to weld a new community on different levels and through different musical repertories. In the words of a distinguished Ethiopian priest and märigeta ("leader of the däbtära") who has led Ethiopian ritual life in the United States since he received asylum in 1982: "You know in our tradition it is very difficult and that the women do not fit. But young people, the younger 
generation especially, the Sunday School students, they have sing-song together now, with women. And that's different from our Yared music. You know, they created it, their sing-song, not Yared."95

Dissent communities are almost always at least partial offspring of the forces they challenge, hence the close and interactive relationship between descent and dissent, and the possibility that they can, for long periods of time, overlap. One does not need revolutions or refugees to give rise to such outcomes; we can find similar, if perhaps more subtle ways in which musics of dissent may emerge as an outgrowth of processes of descent. The case of "early music" and its associated community in the Western art music tradition. provides a salient example. ${ }^{96}$ Succinctly defined as "an interest and involvement with music of the past," has been termed the early-music movement in fact redefines and dissents against mainstream Western musical values. Early-music performances, while commencing with a clearly articulated goal to bring little-performed repertory from the past to life, in fact generated a full range of innovations in the realm of instrumental construction as well as in performance practices. Most tellingly, the emergence of early music gave rise to intense ideological debates, part of what has been said to have became a struggle for values since preferring one interpretation over another "amounts to a manifesto pro or contra authenticity." 98 That the process of performing early music sparked the emergence of a lively new musical community is articulated through numerous social and musical outcomes: the founding of new ensembles and new institutions, such as concert series and festivals at which the community faithful gathered, posited within growing national and international networks. ${ }^{99}$ While the early-music movement generated a following among individuals actively engaged with the ideological issues at stake in Western performance repertories and styles, it also generated a broader following among those less knowledgeable or simply unconcerned about the issues, those who were attracted to this musical domain by exciting new sounds and colorful performance styles. ${ }^{100}$ Here we arrive at a third category of processes generating a musical collectivity: processes of affinity.

\section{$<\mathrm{B}>$ Processes of affinity}

$<\mathrm{fl}>\mathrm{A}$ third type of community, defined largely by affinity, emerges first and foremost from individual preferences, quickly followed by a desire for social proximity or association with 
others equally enamored. Music proves to be a particularly powerful mechanism for catalyzing affinity communities, in which straightforward aesthetic and personal preferences may, but do not necessarily, intersect with other powerful diacritica such as ethnic identity, age cohort, or gender identity. But ultimately, affinity communities derive their strength from the presence and proximity of a sizeable group and for the sense of belonging and prestige that this affiliation offers. The acquisition of cultural capital inevitably plays a role in the emergence and maintenance of communities of affinity, with financial gain frequently providing motivation for shaping a musical style or event that will engender the devoted affiliation of many.

$<\mathrm{txt}>$ At moments, the raw power of affinity is such that a chance encounter can spark a lifelong engagement with a musical tradition not otherwise part of an individual's purview, providing a "conversion experience" of the sort recalled by composer Evan Ziporyn when he heard a recording of Balinese gamelan music while an undergraduate at Yale. ${ }^{101}$ Affinity generally joins an individual to others engaged with a musical style or tradition, so that the individual becoming part of "charmed circles of like-minded music makers drawn magnetically to a certain genre that creates strong expressive bonding." 102

A variety of motivations can be accommodated under affinity, linked on various levels to an array of personal predilections and affective responses. Musical affinity can be driven by sheer sonic attraction, whether based in a desire for the familiar or search for the new; it can catalyze a preoccupation with what is perceived as exotic. The role of a charismatic musician or performer is often a particularly powerful element added to the musical draw in the case of affinity communities. Whatever the basis of the attraction, an affinity community assumes its shape based in the first instance on individual volition, in contrast to motivations deriving from ascribed or inherited factors (descent) or driven by specific ideological commitments or connections (dissent).

Most domains of popular music fit comfortably under the umbrella of affinity; the huge crowds at Rolling Stones concerts speak legions about the power of affinity as the catalyst of a dual musical and social experience. One can at moments find thinly veiled aspects of descent feeding into motivation for affinity, as can be seen in communities surrounding a variety of dance traditions ranging from contra-dance to the tango. Although pop concerts of Christian rock music may seek to attract an affinity community, in truth many different religious denominations seek to expand their own boundaries through musical processes. In other cases, traditions 
initially generated by dissent, for which Jamaican reggae provides an excellent example, quickly transcend their dissent status and attract a sizeable affinity community, continuing to transform themselves over times. Virtually any musical tradition can be acquired through processes driven by affinity, although they do not all necessarily shape a shared social outcome. Such is a case described by Mark Slobin, whose former student "after simply hearing a Highland bagpipe band outside her window, became so attracted to the music that she became a professional piper, not an easy task for a woman in the 1970s." ${ }^{, 103}$ A process of affinity is clearly at work here, although the social outcome of this process is not elucidated.

Attraction of an affinity community outside those of Ethiopian descent is still relatively unrealized among musicians in the Ethiopian diaspora, although many aspire to reach a broader audience. ${ }^{104}$ Even Ethiopian Christian church musicians acknowledge seeking opportunities to perform outside of the church in order to expose others to their musical tradition. ${ }^{105} \mathrm{~A}$ few Ethiopian musicians in the zemänawi (popular) domain have moved beyond their descent community to attract an affinity community for periods of time; a notable example is the singer Aster Aweke, whose recordings in the early days of world beat reached an international audience. ${ }^{106}$ Mulatu Astatke, a figure on the international jazz scene since the 1960s as the innovator of Ethio-jazz, has performed actively internationally for decades and in 2005 had his music used for a popular movie soundtrack. ${ }^{107}$

Yet even in musical domains that arise through affinity, subtle traces of descent or dissent may be embedded. Here we can again consider Mulatu's Ethio-jazz. Through the last quarter of the twentieth century and into the twenty-first, Ethio-jazz has provided a musical outlet for young Ethiopians seeking to engage with world jazz and to innovate within a global musical discourse. However, several of Mulatu's most famous Ethio-jazz compositions draw on Ethiopian Orthodox Christian modes and themes used for important seasons in the Church calendar ("Lent Time") and/or evoke instruments, such as the stone gongs called däwäl, sounded to call the faithful to worship in rural churches. ${ }^{108}$ Mulatu's efforts to "extend and develop" Ethiopian music draw on both various baholawi (traditional) styles and Ethiopian Christian zema (chant). ${ }^{109}$ Thus if a growing affinity community is engaged by the unusual harmonies and lively rhythms of Mulatu Astatke's Ethio-jazz, a listener familiar with Ethiopian Christian musical practices or Ethiopian ethnic musics would perceive aspects of descent embedded within. 
Musical communities shaped by affinity can be enormously dynamic, quickly traveling over great distances and accruing new and heterogeneous content and devotees. The processes of affinity partner well with new technologies, discussed in more detail below, which circulate music to settings (and listeners) it would otherwise not reach. Although both descent and dissent communities have the potential for transnational dispersion, an affinity community actively seeks its own dispersal across boundaries as well as engagement by large groups.

\section{$<\mathrm{A}>\mathrm{IV}$. The Study of Musical Communities in a Changing Scholarly World}

$<\mathrm{fl}>$ The typology of musical communities discussed above aims to provide "translation terms" that could enhance comparative moves in very complex musical and social worlds; it also offers expansion of a terminological domain of "community" shared across cultural boundaries, thus closing the distance between insider notions and scholarly discourse. Rather than bracketing as separate "types" the three categories of collectivity discussed here, one might better consider them as existing along a continuum that can move in different directions or become part of a multidimensional framework. ${ }^{110}$ At moments, multiple communities can be superimposed in one "real place" or within a single musical event. Depending on the ethnographic or historical data, a given musical community may be more clearly located along one region of the continuum presented in Figure 1. ${ }^{111}$ Another might span the entire length of the continuum at a given point in time or generate different communities at different historical moments.

\section{[Fig. 1 here]}

$<\mathrm{txt}>$ The use of a continuum of communities has the additional potential for tracking changes in scale or size over the course of time. ${ }^{112}$ While descent communities invoke identities that tend to be shared by people over a substantial period of time, whether based on ethnicity, nationality, or belief, communities inevitably vary in size at different moments, establishing different historical trajectories.

\section{$<\mathrm{B}>$ Crosscutting factors}

$<\mathrm{fl}>$ Several factors are relevant to all three types of musical community, and brief consideration of them can add texture to this discussion. For instance, a charismatic musician often leads the 
way in processes of community formation, whether as a composer or as a performer. Individual agency can play a decisive role in a descent community associated with a religious order, as a focal point for promulgating dissent, or as the center of attention that gives rise to strong feelings of affinity. One can immediately think of the generative role played by leading musicians who, through their musical creativity and leadership, established liturgical orders that served as the basis for worship communities over the course of centuries. From Ethiopia's St. Yared to Lutheran Germany's J. S. Bach, we have had no shortage of musicians who through their creativity and performance skills (or mythologies thereof) helped generate, extend, and maintain communities of prayer.

$<\mathrm{txt}>$ Nowhere is the role of charismatic musicians more prominent than in communities of dissent, where a leader will often serve to galvanize a new social movement. If Bob Dylan and Joan Baez were the troubadours of the American counterculture beginning in the late 1950s, the voices of countless other musicians have provided rallying points for political initiatives around the world. ${ }^{113}$ Among Ethiopians worldwide, the zemänawi musician Tewodros Kassahun ["Teddy Afro"] has galvanized dissent and social action, at once a symbol of resistance and a focal point around which a new international collectivity has arisen. ${ }^{114}$ Almost without exception, an affinity community rests on the talent and charisma of a powerful musical figure, forging collectivities of followers through the leader's living presence and, after his or her death, through memories of their music and impact.

A second crosscutting factor in the constitution of musical communities is the role of rapidly changing technologies. ${ }^{115}$ The potential for communication of any musical event or style, whatever the technological medium, has a capacity for constructing a community. The burgeoning of affinity communities in the popular domain has benefited from the many channels through which music can travel, and the impact of mass communications has the potential to convey a single musical act of dissent worldwide within hours or to transmit the musical practices of the most well-bounded descent community into new domains. Technology has extended through global networks the reach of what might in the past have been isolated diaspora communities. As technologies of communication are shared, one also finds the overt construction of symbols, with websites and video postings representing the community to a broader public. Technological factors thus shape musical communities from within and in their relationship to others. ${ }^{116}$ 
A third crosscutting factor is the role of music both as a potential force for cohesion and as a source of cultural ferment. Music engages both of these tasks in dissent communities, pushing back in one direction at the same time as it seeks to entice new individuals to its fold. ${ }^{117}$ Music can help a group cohere, while it can also serve as a device that solidifies boundaries in less than promising ways for the future. The Ethiopian liturgical case study again provides a thoughtful example: Performance of the Ethiopian Christian liturgy in diaspora serves as a lure for the faithful with memories of the past, but also threatens prospects for the future given the dearth of institutional and educational resources to insure transmission of the Ge'ez liturgy in diaspora. $^{118}$

$<\mathrm{B}>$ Musical communities in crossdisciplinary perspective

$<\mathrm{fl}>$ The approach to musical communities sketched above is not intended to be prescriptive, but rather to serve as an analytical tool, one that tracks both social/musical relationships and their outcomes. This is not intended as a fixed framework into which individual communities can or should be pigeonholed, nor is it a political project that seeks a return to more homogeneous and exclusionary notions of music or its social impact. ${ }^{119}$ Any given community may contain elements of the three categories; this serves from the start to blur boundaries that might be perceived as quite impenetrable.

$<$ txt $>$ Although there have been initiatives to alter or discard altogether the notion of community in musical scholarship, that most of these efforts to date have not been successful speaks to the need to revisit and rethink the word. But while this essay began with a call for attention to the lack of terminological consensus, it ends with broader concerns that in forfeiting explorations of community, music scholars may miss an opportunity to join broader conversations. Musical scholarship has moved away from explicit discussions of community at precisely the moment when the subject has finally come of age. The manner in which communities are defined and bounded is of deep interest to social scientists, as the frequent references from cultural sociology cited throughout my discussion demonstrate. We have seen that musical communities retain the traces of dual musical and social processes, allowing us to sketch with greater clarity the ways in which these collectivities arise, as well as the varying manners in which they seek to affirm common causes or to articulate deeply felt differences. 
Musical communities provide particularly striking case studies of processes of boundary formation since specific musical styles can lead the way in either closing off a community or in opening it up to outsiders. ${ }^{120}$ As we have seen in the Ethiopian case studies surveyed briefly above, musical processes serve to articulate differences on numerous levels. That the Ethiopian Orthodox Church created and nurtured its own distinctive chant, instrumental, and dance traditions accentuated early on the linguistic and cultural boundaries established against the other Eastern Orthodox Churches. Ethiopian Christian liturgical music provided a particularly significant vehicle for liturgical separation from the Coptic Church of Egypt, which until 1953 held nominal Patriarchal control over the Ethiopians. ${ }^{121}$ During the late twentieth century, in the wake of the Ethiopian revolution, the emergence of the Sunday School songs in Amharic have served to redefine social boundaries as well as realign power relations within Ethiopian churches. The performance of the Ge'ez musical liturgy that was long the exclusive domain of the Ethiopian clergy and its highly trained musicians has in the past twenty years undergone dramatic changes. The introduction of congregational hymns has fractured long-standing boundaries between clergy and congregation, enabling entry of congregants, most particularly women, into aspects of liturgical musical performance previously closed to them. In this context, increasing heterogeneity of musical styles provides data not just about changing musical content in religious life; it constitutes a lively process driving social change and transforms aspects of exclusion and inclusion that have reshaped community constitution and power structures.

The reality of human mobility and the increasing complexity of social relations both enable and complicate the study of musical communities in the twenty-first century. ${ }^{122} \mathrm{My}$ discussion was provoked in the first instance by an attempt to understand the impact of forced migration and diaspora resettlement among Ethiopian Americans and the ways in which new musical initiatives have helped shape particular social outcomes. It is not surprising that increasingly widespread diaspora populations, and the challenges of mass migration, have forced scholars to focus on diaspora's borders and strategies for community definition, and to discard older models that sought ideal types. ${ }^{123}$ But it is also clear that music has been implicated in processes of community building, rendering these questions relevant to a very broad swath of musicological inquiry.

Today interest in collective human experience has moved from the humanities and the social sciences into emerging areas of psychology and neuroscience. There is now an active and 
ongoing debate about music's role in human evolution. ${ }^{124}$ Studies investigating music's role in generating social bonding have begun to proliferate, ranging, for example, from an early discussion about the influence of music making on group communication to a more recent inquiry into effects of choral singing and listening on participants' physical and emotional states. ${ }^{125}$ Directly relevant to potential understanding of the impact of music on social bonding are the numerous studies of rhythm and synchronization. ${ }^{126}$

That psychologists and neuroscientists are beginning to examine music as a generative force in human development and social bonding provides an important opening for music scholars interested in community construction through music making. If, as has been noted, "growing evidence from neuroscience . . . suggests that music is biologically powerful, meaning that it can have lasting effects on nonmusical abilities (such as language or attention) during the lifetime of individual humans," 127 the moment for nuanced historical and ethnographic investigations to help understand these processes is at hand. Collaboration across boundaries of the sciences and humanities is inevitably complex, in part because scientists often deal with the grand sweep of evolutionary time while humanists study the (relatively) shorter durations of individual lifetimes or well-bounded historical epochs. However, some music scholars are already grappling with the methodological issues at stake in these potential cross-disciplinary pursuits, providing nuanced ethnographic data based on sophisticated musical knowledge in hope that their studies will deepen the ability of scientists to more fully incorporate musical data. ${ }^{128}$

The measure of a scholarly discipline can be said to depend on its success at multiple and simultaneous quests: to elucidate and bring to light materials and ideas previously unknown or misunderstood; to sharpen methods and theories in order to provide insights that can be queried and debated; and to speak as eloquently as possible in contexts from publications to the classroom about the broader issues that cross boundaries of disciplines and that promise to illuminate the human condition. Through historical, ethnographic, and musical studies, music scholars can partner with those seeking to understand music's role in other domains long inaccessible to humanists. The study of musical communities, past, present, and future, may in fact hold greater potential than we might ever have suspected for cross-disciplinary debate and exploration. This essay therefore ends with a call for more, not less, discussion of musical communities. Before we strike the word "community" from our scholarly vocabulary, we must 
take care to grapple with why the term unsettles us so and what we might forfeit by our failure to engage with it in the future.

\section{$<\mathrm{A}>$ Works Cited}

\section{$<\mathrm{B}>$ Printed Sources}

<bibl>Abbink, Jon. "Ethnicity.” In Encyclopaedia Aethiopica, vol. 2, Wiesbaden: Harrassowitz, 2003, 444-46.

Alleyne, Brian. “An Idea of Community and Its Discontents: Towards a More Reflexive Sense of Belonging in Multicultural Britain.” Ethnic and Racial Studies 25, no. 4 (2002): 607-27.

Anderson, Benedict. Imagined Communities: Reflections on the Origin and Spread of Nationalism. 1983. Revised ed. London: Verso, 1991.

Anshel, Anat, and David A. Kipper. "The Influence of Group Singing on Trust and Cooperation.” Journal of Music Therapy 25 (1988): 145-55.

Appadurai, Arjun. Modernity at Large: Cultural Dimensions of Globalization. Public Worlds 1. Minneapolis and London: University of Minnesota Press, 1996.

Arensberg, Conrad M. “The Community as Object and Sample.” American Anthropologist 63 (1961): 241-64.

Aronson, Dan R. "Ethnicity as a Cultural System: An Introductory Essay." In Ethnicity in the Americas, edited by Frances Henry, 9-19. World Anthropology. The Hague: Mouton, 1976.

Asai, Susan M. "Sansei Voices in the Community: Japanese American Musicians in California." In Musics of Multicultural America: A Study of Twelve Musical Communities, edited by Kip Lornell and Anne K. Rasmussen, 257-85. New York: Schirmer Books, 1997.

Barkin, Elaine, and Lydia Hamessley, eds. Audible Traces: Gender, Identity, and Music. Zurich and Los Angeles: Carciofoli, 1999.

Barth, Fredrik, ed. Ethnic Groups and Boundaries: The Social Organization of Culture Difference; Results of a Symposium Held at the University of Bergen 23rd to 26th of February 1967. Scandinavian University Books. Bergen: Universitetsforlaget; and London: Allen \& Unwin, 1969. Reissued, Long Grove IL: Waveland Press, 1996. 
Baulch, Emma. “Creating a Scene: Balinese Punk’s Beginnings.” International Journal of Cultural Studies 5 (2002): 153-77.

Becker, Howard S. Art Worlds. Berkeley and Los Angeles: University of California Press, 1982.

_. "Ethnomusicology and Sociology: A Letter to Charles Seeger.” Ethnomusicology 33 (1989): 275-85.

Bennett, Andy. "Consolidating the Music Scenes Perspective." Poetics: Journal of Empirical Research on Culture, the Media and the Arts 32 (2004): 223-34.

Bhabha, Homi K. “On Cultural Choice.” In The Turn to Ethics, edited by Marjorie Garber, Beatrice Hanssen, and Rebecca J. Walkowitz, 181-200. New York and London: Routledge, 2000.

Birhanu, [Merigeta] Tsehai. Mazmur Sabhat (Songs of Praise). Addis Ababa: Ethiopian Orthodox Church, ca. 1971.

Blacking, John. "Music, Culture, and Experience.” In Music, Culture, \& Experience: Selected Papers of John Blacking. Edited by Reginald Byron. Chicago and London: University of Chicago Press, 1995, 223-42. Originally published as “The Study of 'Music' as Cultural System and Human Capability," South African Journal of Musicology 4 (1984): 1-15.

Bohlman, Philip V. The Study of Folk Music in the Modern World. Folkloristics. Bloomington: Indiana University Press, 1988.

Bowers, Jane, and Judith Tick, eds. Women Making Music: The Western Art-Tradition 11501950. Urbana: University of Illinois Press, 1986.

Boynton, Susan, and Roe-Min Kok, eds. Musical Childhoods and the Cultures of Youth. Middletown, CT: Wesleyan University Press, 2006.

Brinner, Benjamin. Knowing Music, Making Music: Javanese Gamelan and the Theory of Musical Competence and Interaction. Chicago and London: University of Chicago Press, 1995.

Brown, Howard Mayer. "Pedantry or Liberation? A Sketch of the Historical Performance Movement." In Authenticity and Early Music: A Symposium, edited by Nicholas Kenyon, 27-56. Oxford: Oxford University Press, 1988.

Burgett, Bruce, and Glenn Hendler. "Keywords: An Introduction.” In Keywords for American Cultural Studies, edited by Bruce Burgett and Glenn Hendler, 1-6. New York and London: New York University Press, 2007. 
Celenza, Anna Harwell. “Imagined Communities Made Real: The Impact of Robert Schumann's Neue Zeitschrift für Musik on the Formation of Music Communities in the MidNineteenth Century." Journal of Musicological Research 24 (2005): 1-26.

Chaillot, Christine. "Ethiopian Orthodox Täwahedo Church: Organization Today." Encyclopaedia Aethiopica, vol. 2, Wiesbaden: Harrassowitz, 2005, 427-32.

Chase, Gilbert. America's Music: From the Pilgrims to the Present. Revised 3rd ed. With a foreword by Richard Crawford and a discographical essay by William Brooks. Urbana and Chicago: University of Illinois Press, 1987.

Chernoff, John Miller. African Rhythm and African Sensibility: Aesthetics and Social Action in African Musical Idioms. Chicago and London: University of Chicago Press, 1979.

Cheyne, Andrew, and Amy Binder. "Cosmopolitan Preferences: The Constitutive Role of Place in American Elite Taste for Hip-Hop Music, 1991-2005." Poetics: Journal of Empirical Research on Culture, the Media and the Arts 38 (2010): 336-64.

Clayton, Martin. "Observing Entrainment in Music Performance: Video-based Observational Analysis of Indian Musicians' Tanpura Playing and Beat Marking." Musicae Scientiae 11 (2007): 27-59.

Clayton, Martin, Rebecca Sager, and Udo Will. "In Time with the Music: The Concept of Entrainment and Its Significance for Ethnomusicology." In special issue of ESEM (European Meetings in Ethnnomusicology) CounterPoint, edited by Udo Will, 11 (2004): $3-75$.

Clifford, James. "Diasporas." Cultural Anthropology 9 (1994): 302-38.

- The Predicament of Culture: Twentieth-Century Ethnography, Literature, and Art. Cambridge, MA: Harvard University Press, 1988.

- Routes: Travel and Translation in the Late Twentieth Century. Cambridge, MA: Harvard University Press, 1997.

Cohen, Anthony P. The Symbolic Construction of Community. Chichester, UK: Ellis Horwood; and London and New York: Tavistock Publications, 1985.

“Community, n.” OED Online. November 2010. Oxford University Press. http://www.oed.com.ezpprod1.hul.harvard.edu/view/Entry/37337?rskey=3i15CN\&result=39912\&isAdvanced=tru e (accessed 5 March 2011). 
Crawford, Richard. "Foreword." In Gilbert Chase, America 's Music, From the Pilgrims to the Present, revised 3rd ed., xi-xxiv. Urbana and Chicago: University of Illinois Press, 1987. - "A Hardening of the Categories: 'Vernacular,' 'Cultivated,' and Reactionary in American Psalmody." In American Studies and American Musicology. A Point of View and a Case in Point . I.S.A.M Monographs 4. Brooklyn: Institute for Studies in American Music, Department of Music, School of the Performing Arts, Brooklyn College of The City University of New York, 1975, 16-33.

Cross, Ian. "Is Music the Most Important Thing We Ever Did? Music, Development, and Evolution.” In Music, Mind and Science, edited by Suk Won Yi, 10-39. Seoul: Seoul National University Press, 1999. Available online at http://www.mus.cam.ac.uk/ ic108/MMS/ (accessed 25 March 2011).

Crossley, Nick. "The Man Whose Web Expanded: Network Dynamics in Manchester's Post/Punk Music Scene 1976-1980." Poetics: Journal of Empirical Research on Culture, the Media and the Arts 37 (2009): 24-49.

Danielson, Virginia. The Voice of Egypt: Umm Kulthüm, Arabic Song, and Egyptian Society in the Twentieth Century. Chicago Studies in Ethnomusicology. Chicago: University of Chicago Press, 1997.

Dreyfus, Laurence. "Early Music Defended against Its Devotees: A Theory of Historical Performance in the Twentieth Century." Musical Quarterly 69 (1983): 297-322.

Erikson, Eric H. Dimensions of a New Identity. Jefferson Lecture in the Humanities, 1973. New York: Norton, 1974.

Erlmann, Veit. "Communities of Style: Musical Figures of Black Diasporic Identity." In Identity and the Arts in Diaspora Communities, edited by Thomas Turino and James Lea, 81-92. Warren, MI: Harmonie Park, 2004.

Fassler, Margot Elsbeth. Gothic Song: Victorine Sequences and Augustinian Reform in TwelfthCentury Paris. Cambridge: Cambridge University Press, 1993.

Feld, Steven, and Keith H. Basso, eds. Senses of Place. Sante Fe, NM: School of American Research Press, 1996.

Fikentscher, Kai. “You Better Work!”: Underground Dance Music in New York City. Hanover, NH, and London: University Press of New England [Wesleyan University Press], 2000. 
Finnegan, Ruth H. The Hidden Musicians: Music-Making in an English Town. Cambridge: Cambridge University Press, 1989.

Foucault, Michael, and Jay Miskowiec. “Of Other Spaces.” Diacritics 16 (1986): 22-27.

Frishkopf, Michael. "Introduction: Music and Media in the Arab World and Music and Media in the Arab World as Music and Media in the Arab World: A Metadiscourse." In Music and Media in the Arab World, edited by Frishkopf, 1-64. Cairo: American University in Cairo Press, 2010.

Gardner, Robert Owen. "The Portable Community: Mobility and Modernization in Bluegrass Festival Life.” Symbolic Interaction 27 (2004): 155-78.

Gidal, Marc Meistrich. "Crossing and Purifying Boundaries: The Music of Umbanda and Quimbanda within the Afro-Gaucho Religious Community of Southernmost Brazil.” PhD diss., Harvard University, 2010.

Gillespie, Angus. "Folk Festival and Festival Folk in Twentieth-Century America." In Time out of Time: Essays on the Festival, edited by Alessandro Falassi, 152-61. Albuquerque: University of New Mexico Press, 1987.

Gleason, Philip. "Identifying Identity: A Semantic History." Journal of American History 69 (1983): 910-31.

Guilbault, Jocelyne. “Audible Entanglements: Nation and Diasporas in Trinidad's Calypso Music Scene." Small Axe, no. 17 (2005): 40-63.

Guilbault, Jocelyne, with Gage Averill, Edourd Benoit, Gregory Rabess. Zouk: World Music in the West Indies. Chicago and London: University of Chicago Press, 1993.

Habte-Sellassie, Abraham. Saint Yared and Ethiopian Ecclesiastical Music. Washington, DC: Debre Selam Kidist Mariam Church, 1999.

Hafkin, Nancy J. "“ 'Whatsupoch' on the Net: The Role of Information and Communication Technology in the Shaping of Transnational Ethiopian Identity.” In Shelemay and Kaplan, "Creating the Ethiopian Diaspora," 221-45.

Haile, Getatchew. "Ethiopian Orthodox (Täwahedo) Church.” In Encyclopaedia Aethiopica, vol 2, Wiesbaden: Harrassowitz, 2005, 414-21.

. “A New Look at Some Dates of Early Ethiopian History." Le Muséon 95 (1982): 31122. Revised version in International Journal of Cultural Studies 6 (2003): 313-33. 
Halberstam, Judith. "What's That Smell? Queer Temporalities and Subcultural Lives." The Scholar \& Feminist Online 2.1 (2003): 1-3.

http://www.bernard.edu/sfonline/ps/halberst.htm (accessed 23 March 2011).

Hall, Kathleen D. "The Ethnography of Imagined Communities: The Cultural Production of Sikh Ethnicity in Britain." Annals, AAPSS (The Annals of the Americanl Academy of Political and Social Science) 595 (2004): 108-21.

Hammessley, Lydia. "Introduction." In Audible Traces. Gender, Identity, and Music, edited by Elaine Barkin and Lydia Hammessley, xvii-xxix. Zurich and Los Angeles: Carciofoli, 1999.

Hannon, Erin E., and Sandra E. Trehub. "Tuning In to Musical Rhythms: Infants Learn More Readily than Adults." Proceedings of the National Academy of Sciences of the United States of America 102 (2005): 12639-43.

Hebdige, Dick. Subculture: The Meaning of Style. London: Methuen, 1979.

Hobsbawm, Eric. "Introduction: Inventing Traditions." In The Invention of Tradition, edited by Eric Hobsbawm and Terence Ranger, 1-14. Cambridge: Cambridge University Press, 1983.

Huq, Rupa. "Rethinking Subculture: A Critique for the Twenty-First Century." In Beyond Subculture: Pop, Youth and Identity in a Postcolonial World. London: Routledge, 2006, 9-24.

Joseph, Miranda. “Community.” In Keywords for American Cultural Studies, edited by Bruce Burgett and Glenn Hendler, 57-60. New York and London: New York University Press, 2007.

Kane, Thomas Leiper. Amharic-English Dictionary. 2 vols. Wiesbaden: Otto Harrassowitz, 1990.

Kaplan, Steven. "Vital Information at Your Fingertips: The Ethiopian Yellow Pages as a Cultural Document." In Shelemay and Kaplan, "Creating the Ethiopian Diaspora," 247-63.

Kendrick, Robert L. The Sounds of Milan, 1585-1650. Oxford and New York: Oxford University Press, 2002.

Kirschner, Sebastian, and Michael Tomasello. "Joint Drumming: Social Context Facilitates Synchronization in Preschool Children." Journal of Experimental Child Psychology 102 (2009): 299-314. 
Kreutz, Gunter, Stephan Bongard, Sonja Rohmann, Volker Hodapp, and Dorothea Grebe.

"Effects of Choir Singing or Listening on Secretory Immunoglobulin A, Cortisol, and Emotional State." Journal of Behavioral Medicine 27 (2004): 623-35.

Lamont, Michèle, and Virág Molnár. "The Study of Boundaries in the Social Sciences." Annual Review of Sociology 28 (2002): 167-95.

Leslau, Wolf. “Community.” In English-Amharic Context Dictionary, Wiesbaden: Otto Harrassowitz, 1973, 221.

Levine, Victoria Lindsay. “American Indian Musics, Past and Present.” In The Cambridge History of American Music, edited by David Nicholls, 3-29. Cambridge: Cambridge University Press, 1998.

Lewis, George E. A Power Stronger Than Itself: The AACM and American Experimental Music. Chicago and London: University of Chicago Press, 2008.

Lockwood, Lewis. Music in Renaissance Ferrara, 1400-1505: The Creation of a Musical Center in the Fifteenth Century. Cambridge, MA: Harvard University Press, 1984.

Lornell, Kip, and Anne K. Rasmussen, eds. Musics of Multicultural America: A Study of Twelve Musical Communities. New York: Schirmer Books, 1997.

Lynd, Robert S., and Helen Merrell Lynd. Middletown, a Study in Contemporary American Culture. San Diego, New York and London: Harcourt, Brace, 1930. Reprinted 1957 with the title Middletown: A Study in American Culture.

Lyons, Terrence. "Transnational Politics in Ethiopia: Diasporas and the 2005 Elections." In Shelemay and Kaplan, "Creating the Ethiopian Diaspora, 265-84.

Lysloff, René T. A. "Musical Community on the Internet: An On-Line Ethnography." Cultural Anthropology 18 (2003): 233-63.

Marcus, Scott. "Creating a Community, Negotiating Among Communities: Performing Middle Eastern Music for a Diverse Middle Eastern and American Public." In Performing Ethnomusicology: Teaching and Representation in World Music Ensembles, edited by Ted Solis, 202-12. Berkeley and Los Angeles: University of California Press, 2004.

McCann, James. "A Response: Doro Fänta; Creativity vs. Adaptation in the Ethiopian Diaspora." In Shelemay and Kaplan, "Creating the Ethiopian Diaspora," 381-88.

McNeill, William H. Keeping Together in Time: Dance and Drill in Human History. Cambridge, MA: Harvard University Press, 1995. 
Müller, C. Detlef G., and Lothar Störk. "Coptic Church.” In Encyclopaedia Aethiopica, vol. 1, Wiesbaden: Otto Harrassowitz, 2003, 797-801.

Nancy, Jean-Luc. La communauté désoeuvrée. 1986. Paris; C. Bourgois, 1990. Translated by Peter Conner et al. as The Inoperative Community. Edited by Peter Connor. Theory of History and Literature 76. Minneapolis: University of Minnesota Press, 1991.

Nicholls, David. The Cambridge History of American Music. Cambridge: Cambridge University Press, 1998.

Noy, Chaim. A Narrative Community. Voices of Israeli Backpackers. Raphael Patai Series in Jewish Folklore and Anthropology. Detroit: Wayne State University Press, 2007.

Pachucki, Mark A., Sabrina Pendergrass, and Michèle Lamont. "Boundary Processes: Recent Theoretical Developments and New Contributions.” In "Culture Lines: Emerging Research on Boundaries," edited by Mark A. Pachucki, Sabrina Pendergrass, and Michéle Lamont, special issue of Poetics: Journal of Empirical Research on Culture, the Media and the Arts 35 (2007): 331-51.

Patel, Aniruddh D. "Music, Biological Evolution, and the Brain." In Emerging Disciplines: Shaping New Fields of Scholarly Inquiry Beyond the Humanities, edited by Melissa Bailar, 41-64. Houston, TX: Rice University Press, 2010.

- Music, Language, and the Brain. Oxford and New York: Oxford University Press, 2008. Peraino, Judith A. Listening to the Sirens. Musical Technologies of Queer Identity from Homer to Hedwig. Berkeley and Los Angeles: University of California Press, 2006.

Ranger, Terence O. "The Invention of Tradition Revisited: The Case of Colonial Africa." In Legitimacy and the State in Twentieth-Century Africa: Essays in Honour of A. H. M. Kirk-Greene, edited by Terence O. Ranger and Olufemi Vaughan, 62-111. St. Anthony's/Macmillan Series. London: Macmillan, in association with St. Antony’s College, Oxford, 1993.

Rees, Helen, ed. Lives in Chinese Music. Urbana and Chicago: University of Illinois Press, 2009. Reyes, Adelaida. Songs of the Caged, Songs of the Free: Music and the Vietnamese Refugee Experience. Philadelphia: Temple University Press, 1999.

Rheingold, Howard, ed. The Virtual Community: Homesteading on the Electronic Frontier. 1993. Revised ed. London and Cambridge, MA: MIT Press, 2000. 
Rose, Nikolas. “Community.” In Powers of Freedom, Reframing Political Thought, 167-96. Cambridge: Cambridge University Press, 1999.

Said, Edward W. "Figures, Configurations, Transfigurations." Race \& Class 32 (1990): 1-16.

"Scene, n." OED Online. November 2010. Oxford University Press. http://www.oed.com.ezpprod1.hul.harvard.edu/view/Entry/172219?redirectedFrom $=$ scene (accessed 5 March 2011).

Schaefer, Charles G. H. "Mahbär.” In Encyclopaedia Aethiopica, vol 3, Wiesbaden: Otto Harrassowitz, 2007, 649-50.

Schramm, Adelaida Reyes. "Ethnic Music, the Urban Area, and Ethnomusicology," Sociologus 29 (1979): 1-21.

_ . "The Role of Music in the Interaction of Black Americans and Hispanos in New York City's East Harlem.” PhD diss., Columbia University, 1975.

Shanks, Barry. “Transgressing the Boundaries of a Rock 'n' Roll Community.” Paper delivered at the First Joint Conference of IASPM [International Association for the Study of Popular Music]-Canada and IASPM-U.S.A. Yale University, 1 October 1988.

Shelemay, Kay Kaufman. "Ethiopia, II: Orthodox Church Music." In The New Grove Dictionary of Music and Musicians, 2nd ed., edited by Stanley Sadie and John Tyrrell, 8:356-61. London: Macmillan, 2001.

_. "Ethiopian Musical Invention in Diaspora: A Tale of Three Musicians." In Shelemay and Kaplan, "Creating the Ethiopian Diaspora," 303-20.

_Let Jasmine Rain Down: Song and Remembrance among Syrian Jews. Chicago Studies in Ethnomusicology. Chicago and London: University of Chicago Press, 1998.

_. "Music in the Ethiopian American Diaspora: A Preliminary Overview." In Proceedings of the 16th International Conference of Ethiopian Studies, vol. 4, Trondheim 2009, edited by Svein Ege, Harald Aspen, Birhanu Teferra, and Shiferaw Bekele, 1153-64. Trondheim, Norway: NTNU (Norwegian University of Science and Technology). http://www.st.ntnu.no.ices16/Proceedings/Forms/AllItems.aspx [click on vol. 4].

_ "The Musician and Transmission of Religious Tradition: The Multiple Roles of the Ethiopian Däbtära." Journal of Religion in Africa 22 (1992): 242-60.

__. "Performing the Humanities at the Ethiopian Millennium." Daedalus 138 (2009): 1059. 
—_. "Toward an Ethnomusicology of the Early Music Movement: Thoughts on Bridging Disciplines and Musical Worlds." Ethnomusicology 45 (2001): 1-29.

_. "Zema: A Concept of Sacred Music in Ethiopia." World of Music 24 (1982): 52-67. Shelemay, Kay Kaufman, and Peter Jeffery, eds. Ethiopian Christian Liturgical Chant: An Anthology. 3 vols. Madison, WI: A-R Editions, 1993, 1994, 1997.

Shelemay, Kay Kaufman, and Steven Kaplan, eds. "Creating the Ethiopian Diaspora: Perspectives from Across the Disciplines." Special issue, Diaspora 15, no. 2/3 (2006; published 2011).

Shelemay, Kay Kaufman, and Steven Kaplan. "Introduction.” In Shelemay and Kaplan, "Creating the Ethiopian Diaspora," 191-213.

Slobin, Mark. Subcultural Sounds: Micromusics of the West. Hanover, NH: Wesleyan University Press and University Press of New England, 1993.

Small, Christopher. Musicking: The Meanings of Performing and Listening. Music/Culture. Middletown, CT: Wesleyan University Press; and Hanover, NH: University Press of New England, 1998.

Snyder, Joel S., Erin E. Hannon, Edward W. Large, and Morten H. Christiansen.

"Synchronization and Continuation Tapping to Complex Meters." Music Perception 24 (2006): 135-45.

Soja, Edward W. "Heterotopologies." In Postmodern Cities and Spaces, edited by Sophie Watson and Katherine Gibson, 13-34. Cambridge, MA, and Oxford: Blackwell, 1995.

- Thirdspace: Journeys to Los Angeles and Other Real-and-Imagined Places. Cambridge, MA: Blackwell, 1996.

Stokes, Martin, ed. Ethnicity, Identity, and Music: The Musical Construction of Place. Berg Ethnic Identity Series. Oxford and Providence, RI: Berg, 1994.

Straw, Will. "Scenes and Sensibilities." In "Cities/Scenes," edited by Janine Marchessault and Will Straw, special issue of Public 22/23 (2001): 245-57.

—. "Systems of Articulation, Logics of Change: Communities and Scenes in Popular Music." Cultural Studies 5 (1991): 368-88.

Strohm, Reinhard. Music in Late Medieval Bruges. Revised ed. Oxford, Clarendon; New York: Oxford University Press, 1990. 
Sugarman, Jane C. "Building and Teaching Theory in Ethnomusicology: A Response to Rice." Ethnomusicology 54 (2010): 341-44.

Swinehart, Karl F. “The Mass-Mediated Chronotope, Radical Counterpublics, and Dialect in 1970s Norway: The Case of Vømmøl Spellmanslag.” Journal of Linguistic Anthropology 18 (2008): 290-301.

Tick, Judith, ed., with Paul Beaudoin, assistant ed. Music in the USA: A Documentary Companion. Oxford and New York: Oxford University Press, 2008.

Tönnies, Ferdinand. Community and Civil Society. Edited by Jose Harris. Cambridge Texts in the History of Political Thought. Cambridge and New York: Cambridge University Press, 2001.

Turino, Thomas. "Introduction: Identity and the Arts in Diaspora Communities." In Identity and the Arts in Diaspora Communities, edited by Thomas Turino and James Lea, 3-19. Detroit Monographs in Musicology/Studies in Music 40. Warren, MI: Harmonie Park, 2004.

-. Music as Social Life: The Politics of Participation. Chicago Studies in Ethnomusicology. Chicago and London: University of Chicago Press, 2008.

Turner, Victor. "Communitas: Model and Process". In The Ritual Process: Structure and AntiStructure. 1969. Reprint, Ithaca, NY: Cornell University Press, 1977, 131-65.

Veal, Michael E. Fela: The Life \& Times of an African Musical Icon. Philadelphia: Temple University Press, 2000.

Vélez, María Teresa. Drumming for the Gods: The Life and Times of Felipe Garcia Villamil, Santero, Palero, and Abakuá. Studies in Latin American and Caribbean Music. Philadelphia: Temple University Press, 2000.

Wade, Bonnie C. "Fifty Years of SEM in the United States: A Retrospective." Ethnomusicology 50 (2006): 190-98.

Weintraub, Andrew N. "Introduction." In Music and Cultural Rights, edited by Andrew N. Weintraub and Bell Yung, 1-18. Chicago and Urbana: University of Illinois Press, 2009.

Whyte, William Foote. Street Corner Society: The Social Structure of an Italian Slum. 1943. 4th ed. Chicago: University of Chicago Press, 1993. 
Williams, Raymond. "Community." In Keywords: A Vocabulary of Culture and Society, revised ed. New York: Oxford University Press, 1983, 75-76.

Wong, Deborah. Speak It Louder: Asian Americans Making Music. New York and London: Routledge, 2004.

Ziporyn, Evan. “One Man's Traffic Noise: A Case Study in Cross-cultural Collaboration.” Unpublished paper, presented at Berkeley, CA, ca. 1992.

$<$ B $>$ Ethnographic Interviews

$<$ bibl $>$ Astatke, Mulatu

Birhanu, Tsehai

Garede, Getahun Atlaw

Gebregiorgis, Getachew

Habte-Selassie, Abraham

Seyoum, Moges
23 October, 2007

12 April 2008, 17 September 2010

3 August 2008

2 July 2008

12 June 2008

2 August 2007

\section{$<\mathrm{B}>$ Visual and Audio Sources}

<bibl>Astatke, Mulatu. "Dèwèl [däwäl]." éthiopiques 4: Ethio-jazz \& musqiue instrumentale 1969-1974. Paris: Buda Musique 829642, 1998, compact disc.

—. "Lent Time." In Under African Skies: Ethiopia, Executive Producer, Dennnis Marks. London: British Broadcasting Corporation Videos for Education and Training, 1989. Videocassette, 58:12.

Aweke, Aster. Aster. New York: Columbia, CK46848, 1989, compact disc.

éthiopiques. Vols. 1-26. Paris: Buda Musique, 1977-present, compact discs.

Jarmusch, Jim. Broken Flowers. Film. Focus Features, 2005. Available on DVD, Dead Flowers, Inc.

Kassahun, Tewodros [Teddy Afro]. Yasteseryal. 2nd ed. Maryland and New York: Nahum Records, Inc., 2005, compact disc.

Mosbacher, Dee, and Boden Sandstrom. Radical Harmonies. San Francisco: Women Vision, 2002, DVD. 
Tous les matins du monde. Director, Alain Corneau. France: Film par Film, D. D. Productions, Divali Films, Sédif, FR3 Films Production, 1991, 115 minutes.

Tous les matins du monde: Bande originale du film. France: Valois, V4640. Distribution, Auvidis, 1991, compact disc.

Under African Skies: Ethiopia. Dennis Marks, Exec. Producer. Film. Available from London: British Broadcasting Corporation Videos for Education and Training, 1989.

\section{$<\mathrm{A}>$ Abstract}

$<\mathrm{fl}>$ This essay discusses the study of musical communities, taking as its point of departure the growing avoidance of the term "community" within much of recent musical scholarship. After exploring factors that have been responsible for the move away from community studies, the paper details both the creation of new nomenclature and the discourse surrounding the introduction of these new terms. Based on insights drawn from musical ethnography with recent African immigrants to the United States, the paper goes on to propose a revised framework for approaching "community." It suggests that attention to processes of descent, dissent, and affinity both elucidates music's generative role in shaping new collectivities and unsettles the notion of music as a static sonic marker of social groupings. The conclusion touches briefly on new research from the sciences that is beginning to shed new light on music's role in generating social outcomes and the potential it holds for future collaboration with music scholars across disciplinary boundaries.

Keywords: musical communities, Ethiopian music, music and social bonding, boundary studies, community studies

$<$ notes $>1$ Burgett and Hendler, "Keywords: An Introduction," 1.

2 Joseph, "Community," 57.

${ }^{3}$ My theoretical interest in this topic emerged during ethnographic research in the Ethiopian American diaspora during the early 2000s; I thank the many musicians who shared aspects of challenges encountered in reestablishing, and in some cases, reinventing, their musical lives. Preliminary versions of this paper titled "Ethnicity and Beyond: Reconsidering Notions of 
Community in American Life," were delivered at the 2003 annual meeting of the Society for American Music and at the Center for the Humanities and the Arts and American Research Center, University of Colorado, 23 April 2004. I taught two graduate seminars on the topic of "musical communities" at Harvard in 2005 and 2009 and thank members of these two classes for stimulating discussions. Brigid Cohen and Marc Gidal, both participants in the 2005 seminar, have since then completed their own doctoral studies of musical communities and provided invaluable critical suggestions for this paper. I also appreciate the thoughtful comments and suggestions for additional sources received from Aaron Berkowitz, Jocelyne Guilbault, Michèle Lamont, Mark Pachucki, Aniruddh Patel, Adena Schachner, and the anonymous readers for this

Journal. Kiri Miller provided research assistance during the early stages of this work in 2003, as did Bridget Haile and Rachel Sayet during the final preparation of the paper in 2010.

${ }^{4}$ Bhabha, "On Cultural Choice." Bhabha discusses cultural choices "internal to the history of a culture and integral to its communal existence" (189) as decisions that raise ethical concerns and require sensitivity to the full range of negotiations that transpire in the process of community formation. Bhaba's suggestion that a community's internal contradictions must be kept in mind as part of the scholarly process is an important consideration here.

${ }^{5}$ One continues to find community studies in evidence in many scholarly musical settings, such as the panel titled "Making Musical Communities," included in the program of the Seventy-Sixth Annual Meeting of the American Musicological Society, Indianapolis, October 2010. See the AMS Newsletter (August 2010): 14. The move away from the term "community" is more marked in ethnomusicology, despite the fact that studies of social bonding and related phenomena in musical contexts continue apace.

${ }^{6}$ The move toward science in particular was forecast in the final writings of ethnomusicologist John Blacking, who suggested that " 'Music'-making is a special kind of social action which can have important consequences for other kinds of social action.” See Blacking, "Music, Culture, and Experience," 223. See also historian William H. McNeill, who noted that "Moving our muscles rhythmically and giving voice consolidate group solidarity by altering human feelings"; Keeping Together in Time: Dance and Drill in Human History, viii.

${ }^{7}$ These materials, including more than sixty oral histories, sound recordings, and related ephemera, have been deposited in the Library of Congress American Folklife Center's Archive 
of Folk Culture. I am grateful for the support of the John W. Kluge Center at the Library of Congress and for the resources they provided me as 2007-2008 Chair in Modern Culture. I am also greatly indebted for the release time from teaching to pursue this research supported during 2007-2008 by fellowships from the Radcliffe Institute for Advanced Study at Harvard University, the National Endowment for the Humanities, and the John Simon Guggenheim Memorial Foundation.

${ }^{8}$ The Ethiopian population of the Washington, D.C., metropolitan area is informally estimated at more than 250,000 today. For a series of essays that discuss the history, social, and cultural life of the Ethiopian American diaspora, see Shelemay and Kaplan, "Creating the Ethiopian Diaspora."

${ }^{9}$ The number of Ethiopian and Eritrean musicians living in Washington, D.C., in summer 2007 was estimated at around 150, an informal count that included only professional musicians in the secular domain and excluded numerous liturgical music specialists. See Shelemay, "Music in the Ethiopian American Diaspora."

${ }^{10}$ Wade, "Fifty Years of SEM in the United States," 196.

${ }^{11}$ Turino, Music as Social Life, 94-95.

${ }^{12}$ A representative study of Ghanaian drumming ensembles is Chernoff, African Rhythm and African Sensibility. On the gamelan, see, for example, Brinner, Knowing Music, Making Music.

${ }^{13}$ A notable source is Guilbault et al., Zouk: World Music in the West Indies. Veit Erlmann argues for a connection shared by African diaspora communities between aspects of musical style such as repetition and community building. See Erlmann, “Communities of Style: Musical Figures of Black Diasporic Identity," 83.

${ }^{14}$ As seen in Shelemay, Let Jasmine Rain Down: Song and Remembrance among Syrian Jews; and Reyes, Songs of the Caged, Songs of the Free: Music and the Vietnamese Refugee Experience.

${ }^{15}$ Regarding European courts, churches, and urban centers, see Lockwood, Music in Renaissance Ferrara, 1400-1505; Fassler, Gothic Song: Victorine Sequences and Augustinian Reform in Twelfth-Century Paris; Strohm, Music in Late Medieval Bruges; and Kendrick, Sounds of Milan, 1585-1650. For collectivities linked by gender, see Bowers and Tick, eds., Women Making Music; and for essays that touch on the power of music in defining interpretive communities, 
Barkin and Hamessley, eds., Audible Traces, esp. the introduction by Hamessley. Regarding gender, Judith A. Peraino's chapter on "Homomusical Communities," in her Listening to the Sirens, 152-94, surveys lesbian and gay communities generated in part by the impact of sound recordings. Mosbacher and Sandstrom's co-produced film Radical Harmonies documents the emergence of the women's music community and samples a wide spectrum of its music. For attention to youthful cohorts, see Boynton and Kok, eds., Musical Childhoods and the Cultures of Youth.

${ }^{16}$ On the latter point, see Danielson, Voice of Egypt; Vélez, Drumming for the Gods; and Rees, ed., Lives in Chinese Music.

${ }^{17}$ See "The Musical Puritans," 3-18, and "Gentlemen Amateurs," 72-93, in Chase, America's Music.

${ }^{18}$ Crawford, Foreword, in Chase, America's Music, xv.

${ }^{19}$ Nicholls, Cambridge History of American Music. Judith Tick, ed., in Music in the USA, presents an array of documents that touch on many issues of community in the United States, ranging from "The Fasola Folk," (133-38), linked to each other by shape-note singing, to musical initiatives intended for political demonstrations by members of the Composers' Collective (463-65), among others. See also Lewis, Power Stronger than Itself, 88, for a view of the AACM as a venue for bringing together black musicians of diverse backgrounds to develop both music and the music business.

${ }^{20}$ One can find incisive discussions of community in other disciplines. See Gardner, "Portable Community: Mobility and Modernization in Bluegrass Festival Life," 156, for a summary of some recent contributions from the sociological literature, suggesting that community "has become a word that, like art or pornography, is clearly recognizable yet is variously defined." ${ }^{21}$ Lornell and Rasmussen, eds., Musics of Multicultural America. The single index entry for community is found in one essay discussing third-generation Japanese American musicians in California, linking music, ethnicity, and community memory. See Asai, "Sansei Voices in the Community. Japanese American Musicians in California," in ibid., 261. More recent publications continue to explore ways in which "performance is a site of cultural production": Wong, Speak It Louder, 4, mentions, while not focusing on, community per se, but she does not stress the heterogeneous nature of Asian American agency and political critique expressed through socio- 
musical gatherings such as karaoke (ibid., 86-87).

${ }^{22}$ Marcus, "Creating a Community, Negotiating Among Communities"; Lysloff, "Musical Community on the Internet"; and Weintraub, "Introduction," 3.

${ }^{23}$ Turino, Music as Social Life, 95 (emphasis in the original).

${ }^{24}$ See ibid., chap. 7, "Music and Political Movements," 189-224.

${ }^{25}$ Ibid., 2. See also Turino's comment regarding contra dancing as constituting the "basis of a cultural cohort: a social group that forms around the activity itself." (ibid., 187)

${ }^{26}$ Crawford, "Hardening of the Categories"; Levine, "American Indian Musics," 29; and Fikentscher, “You Better Work!”: Underground Dance Music in New York City, 107.

${ }^{27}$ Williams, "Community," in Keywords, 75-76.

28 “Community, n.” OED Online. November 2010. Oxford University Press.

http://www.oed.com.ezp-

prod1.hul.harvard.edu/view/Entry/37337?rskey=3i15CN\&result=39912\&isAdvanced=true (accessed 5 March 2011).

${ }^{29}$ Ibid.

${ }^{30}$ In a lateral move, musical scholarship has explored the relationship of music and place from a more cosmopolitan and experiential perspective. See Feld and Basso, eds., Senses of Place; and Stokes, ed., Ethnicity, Identity, and Music. The notion of place is currently being reappraised in cultural sociology: See Cheyne and Binder, "Cosmopolitan Preferences: The Constitutive Role of Place in American Elite Taste for Hip-Hop Music, 1991-2005.”

${ }^{31}$ See Tönnies, Community and Civil Society, 17.

${ }^{32}$ See Lynd and Lynd, Middletown; Whyte, Street Corner Society: The Social Structure of an Italian Slum; Arensberg, "Community as Object and Sample."

${ }^{33}$ Barth, ed. Ethnic Groups and Boundaries; Aronson, "Ethnicity as a Cultural System”; and Gleason, "Identifying Identity: A Semantic History."

${ }^{34}$ Schramm, "Role of Music in the Interaction of Black Americans and Hispanos in New York City’s East Harlem." See also idem, "Ethnic Music, the Urban Area, and Ethnomusicology." ${ }^{35}$ See, for example, Alleyne, "Idea of Community and Its Discontents," which offers a critique of the homogenizing impact of the concept of community as applied to minority groups in early twenty-first century Britain. I thank Marc Gidal for bringing this article to my attention. See also 
Noy, Narrative Community: Voices of Israeli Backpackers, 151-52.

${ }^{36}$ For a summary of literature on boundaries, see Lamont and Molnár, "Study of Boundaries in the Social Sciences"; and Pachucki, Pendergrass, and Lamont, "Boundary Processes: Recent Theoretical Developments and New Contributions."

${ }^{37}$ While I here mention three important works from political science, social anthropology, and history, there are other writings that contributed to the general field of community studies around this time. Their number includes philosopher Jean-Luc Nancy's La communauté désoeuvrée, with subsequent revised and augmented editions in 1990 and 1999. The volume appeared in English as The Inoperative Community. Nancy explores the philosophical limits of community, suggesting that "finitude, or the infinite lack of infinite identity, if we can risk such a formulation, is what makes community. That is, community is made or is formed by the retreat or by the subtraction of something: this something, which would be the fulfilled infinite identity of community, is what I call its 'work.' . . But in fact it is the work that the community does not do and that it is not that forms community" (xxxviii-xxxix).

${ }^{38}$ Anderson, Imagined Communities, 3-4.

${ }^{39}$ Ibid., 6-7.

${ }^{40}$ Anderson's theoretical influence on recent ethnomusicological work includes Frishkopf, "Introduction," in Music and Media in the Arab World, 22-23; and Sugarman, "Building and Teaching Theory in Ethnomusicology." In historical musicology, see Celenza, "Imagined Communities Made Real: The Impact of Robert Schumann's Neue Zeitschrift Für Musik on the Formation of Music Communities in the Mid-Nineteenth Century."

${ }^{41}$ Cohen, Symbolic Construction of Community, 19-20.

${ }^{42}$ Ibid., 21.

${ }^{43}$ Ibid., 108.

${ }^{44}$ Hobsbawm and Ranger, eds., Invention of Tradition.

${ }^{45}$ Hobsbawm, "Introduction: Inventing Tradition," 1-2. Ranger later discarded the term invention in lieu of "imagination." See Ranger, "Invention of Tradition Revisited."

${ }^{46}$ Clifford, Predicament of Culture; and idem, Routes. Travel and Translation in the Late Twentieth Century. Subsequent works, such as Appadurai, Modernity at Large, 2-5, set forth the multiple shifts in electronic media and mass migration that mark what he has termed "the global 
now" and enhance the "work of the imagination."

${ }^{47}$ Soja, Thirdspace, 1. A subsequent analysis of the thirdspace community further argued that it is a site for the exercise of political power, situated between the authority of the state and the rights of the individual, while remaining at the same time as a counterweight to potential abuses. The growing engagement with music's role in political life and in forging moral communities is presaged by Nikolas Rose, who writes: "The community of the third sector, the third space, the third way of governing is not primarily a geographical space, a social space, a sociological space or a space of services, although it may attach itself to any or all such spatializations. It is a moral field binding persons into durable relations." See Rose, "Community," 172.

${ }^{48}$ Williams, "Community," 75.

49 Joseph, "Community," 57.

${ }^{50}$ Hebdige, Subculture. See also Bennett, “Consolidating the Music Scenes Perspective,” 224, for a brief history and critique of the subculture concept. For a lengthier critical consideration of subculture, see Huq, "Rethinking Subculture.” I thank Jocelyne Guilbault for directing me to Huq's work on this topic.

${ }^{51}$ Slobin, Subcultural Sounds.

52 Ibid., 98-106.

${ }^{53}$ Becker, Art Worlds.

${ }^{54}$ However, Becker was invited to deliver the 1988 Charles Seeger Memorial Lecture of the Society for Ethnomusiciology, published as Becker, "Ethnomusicology and Sociology: A Letter to Charles Seeger."

${ }^{55}$ Finnegan, Hidden Musicians: Music-Making in an English Town, 31-32.

${ }^{56}$ Ibid., 304-5

${ }^{57}$ Ibid., 305-6.

${ }^{58}$ Ibid., 306.

${ }^{59}$ Ibid., 299.

${ }^{60}$ Ibid., 355-56n3.

${ }^{61}$ Slobin, Subcultural Sounds, 40. Slobin describes musical pathways as a homogenizing framework, one that does not accommodate "so much as a gram of the oppositional" (41).

${ }^{62}$ Said, "Figures, Configurations, Transfigurations"; Shanks, "Transgressing the Boundaries of a 
Rock 'n' Roll Community"; and Straw, "Systems of Articulation, Logics of Change," 373.

${ }^{63}$ Straw, "Systems of Articulation," 369.

${ }^{64}$ Bennett, "Consolidating the Music Scenes," 224.

${ }^{65}$ Ibid., 224.

${ }^{66}$ Straw, "Scenes and Sensibilities," 248. I thank Jocelyne Guilbault for this reference.

${ }^{67}$ Straw, "Systems of Articulation," 373.

${ }^{68}$ Ibid., 380-81.

69 “Scene, n." OED Online. November 2010. Oxford University Press. http://www.oed.com.ezpprod1.hul.harvard.edu/view/Entry/172219?redirectedFrom=scene (accessed 5 March 2011).

${ }^{70}$ Straw, "Systems of Articulation," 375.

${ }^{71}$ Slobin, Subcultural Sounds, 11-12.

72 Guilbault, “Audible Entanglements: Nation and Diasporas in Trinidad's Calypso Music Scene," 40. Music can generate a sense of shared identity that may be transitory or that may be part of a process that reinforces belonging to a collectivity of longer duration. The more transitory aspect of music's power, commonly termed communitas after its formative use by anthropologist Victor Turner, is less my subject here, but I do wish to propose that music's ability to generate social bonding is an important aspect of performance's centrality to communities of longer duration as well. For a lengthy exposition by Turner on various categories of communitas he set forth based on both ethnographic and historical data, see "Communitas: Model and Process." The impact of music on social bonding has, as noted above, recently engaged scientific attention, an emerging field that will be discussed in the conclusion. 73 Alleyne, "Idea of Community," 608.

${ }^{74}$ Implicit to this definition is the proposal that processes of community formation are generated and sustained in part through musical performance. Here I find relevant Christopher Small's suggestion that we render music as a verb: "To music is to take part, in any capacity, in a musical performance, whether by performing, by listening, by rehearsing or practicing, by providing material for performance (what is called composing), or by dancing"; Small, Musicking, 9 (italics in original). Small's broad notion of the act of "musicking," takes into account its social dimension, including "all the activities that affect the nature of that event which is a performance" (11). 
${ }^{75}$ Here I focus on Ethiopian people and practices from the central Ethiopian highland plateau who speak Amharic, which was the official national language before the 1974 Ethiopian revolution and continues to be spoken widely both in Ethiopia and in diaspora. These Amharic terms and concepts have been widely disseminated among a wide cross section of the Ethiopian populations, most of whom spoke Amharic in addition to a language associated with their particular ethnic or regional communities. All of the terms discussed here were well established historically and are today actively perpetuated among Ethiopian immigrants in the American diaspora. The definitions of "community," in Leslau, English-Amharic Context Dictionary, 221, date from the period before the Ethiopian revolution and the subsequent period of forced migration.

${ }^{76}$ Kane, English-Amharic Dictionary, 1:278-79.

${ }^{77}$ Ibid., 1:24.

${ }^{78}$ Leslau, Dictionary, 872; and Kane, Dictionary, 2:2036. Amharic has additional terms for collectivities of special types, such as religious fraternal organizations named mahbär. See Schaefer, "Mahbär." Musicians in both Ethiopia and the United States have founded an

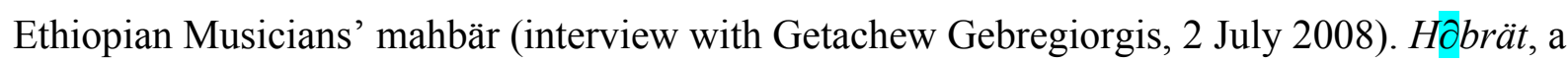
union or association, is another common term for a collective, but in a more political or legal sense; Kane, Dictionary, 1:13.

${ }^{79}$ For a nuanced discussion of ethnicity in Ethiopian daily and political life, see Abbink, "'Ethnicity." There are also publications, such as the Ethiopian Yellow Pages produced in the Washington, D.C., metropolitan area, that can be interpreted as a "text in which issues of identity and community are represented by and for members of the Ethiopian community"; Kaplan, "Vital Information at Your Fingertips: The Ethiopian Yellow Pages, 247. The Ethiopian Yellow Pages includes a substantial section on Ethiopian musicians (ibid., 257).

${ }^{80}$ See Shelemay, “Zema: A Concept of Sacred Music in Ethiopia." Zema (lit., "chant”) in fact subsumes music, dance, and instruments of the Ethiopian Orthodox church rituals. See Shelemay and Jeffery, Ethiopian Christian Liturgical Chant; and Shelemay, "Ethiopia, II: Orthodox Church Music."

${ }^{81}$ See Shelemay, "Performing the Humanities at the Ethiopian Millennium."

${ }^{82}$ Interview with Getahun Atlaw Garede, 3 August 2008. 
${ }^{83}$ Bennett, in "Consolidating the Music Scenes," suggests presenting the music scene as a "trichotomy," "comprising local, trans-local and virtual readings of scene" "(226).

${ }^{84}$ Identity provides a link between the individual and the collective, constituting "a process 'located' in the core of the individual and yet also in the core of his communal culture, a process which establishes, in fact, the identity of those two identities"; Gleason, "Identifying Identity," 914, citing Erikson, Dimensions of a New Identity, 22.

${ }^{85}$ For an overview of Ethiopian Church history and the role of music at the inception of that tradition, see Shelemay and Jeffery, Anthology, 1:3-8.

${ }^{86}$ Habte-Sellassie, Saint Yared and Ethiopian Ecclesiastical Music, 38.

${ }^{87}$ Two of the Ethiopian church musicians I interviewed have written booklets narrating the story of St. Yared, one in English "for the benefit of the English-speaking guest who came to . . . an event held at the church"; Interview with Abraham Habte-Sellassie, 12 June 2008; also see Habte-Sellassie, Saint Yared. The dating of Saint Yared's life has been questioned by Getatchew Haile who suggests that the period of consolidation, traditionally dated to the late fifth or early sixth centuries, may have occurred as late as the ninth; "New Look at Some Dates of Early Ethiopian History." See also Shelemay and Jeffery, Anthology, vols. 1 and 3, for further discussion of this issue. The significance of creative musicians as a central factor in the origin myths of many musical communities will be discussed below.

${ }^{88}$ Ethiopian church musicians (däbtära) were lay clergy separate from the ordained priests and monks. The däbtära alone perform the Mahelet, the musically elaborate cathedral office that

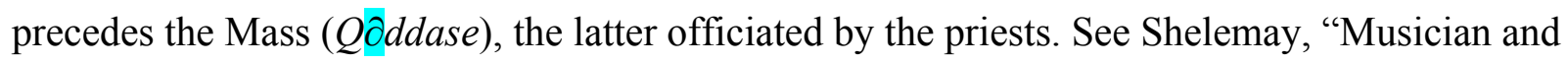
Transmission of Religious Tradition." Only priests and däbtära learn the ancient Semitic language, Ge'ez, in which the Ethiopian Christian liturgical texts are set, and, as a result, the congregation participates very little in liturgical performance. The traditional liturgy, which is transmitted as an oral tradition despite the presence of an indigenous notational system introduced in the sixteenth century, is therefore restricted to the church musicians and the regular clergy. See Shelemay and Jeffery, Anthology.

${ }^{89}$ See Haile, "Ethiopian Orthodox (Täwahedo) Church."

${ }^{90}$ These included the nationalization of Church properties, land, and buildings in 1975 and appointment by the Revolutionary government beginning in this period of church officials and 
administrators. See Chaillot, "Ethiopian Orthodox Täwahedo Church: Organization Today," 428-29. Music also provided a context for substantial changes, as will be clear below.

${ }^{91}$ See, for instance, Gillespie, "Folk Festival and Festival Folk in Twentieth-Century America." Also Bohlman, Study of Folk Music in the Modern World, esp. chap. 4, which explores the social basis of folk music and the resulting sense of community. Many examples exist of dissent communities constituted through musical processes, including the use of music in 1975 by Norwegian telecommunication workers seeking to build solidarity for a strike through releasing a recording, 250 Mann, with a hit Norwegian musical group. See Swinehart, "Mass-Mediated Chronotope, Radical Counterpublics, and Dialect.” Although the striking workers were arguably already linked socially through their alliance at work, the release and circulation of the song led to the incorporation of them and their cause within an emerging dissent group of the early 1970s that came to be known as "Vømmøl Valley," a fictitious rural Norwegian community; ibid., 291. 92 Ethiopian Orthodox churches have been established all over North America, with many cities supporting several churches due to factors ranging from local residential patterns, to ethnic and political divisions, to contested relationships with the mother church in Ethiopia. See Shelemay, "Music in the Ethiopian American Diaspora," 1157.

${ }^{93}$ Dissent and commemoration are not at the center of all Ethiopian diaspora churches. Ethiopian Orthodoxy today has been divided since the period of Eritrean independence in 1991 between Ethiopian and Eritrean churches, as well as along homeland/diaspora lines, with separate patriarchs and church administrations in areas abroad, such as the American diaspora. Therefore, some Ethiopian churches in diaspora maintain an affiliation with the homeland church hierarchy and affirm their status as a descent community. Thus one can find the same Ethiopian Christian liturgy being performed as an emblem of descent and nationalism in homeland-affiliated diaspora churches and as an emblem of dissent and nostalgia in those under a foreign-based patriarch.

94 This innovation was sparked by Father Tsehai Birhanu, an Ethiopian priest and musician who began composing Amharic-language hymns while a student at the Holy Trinity College in Addis Ababa. He was assigned by church officials to teach Bible and song at churches in the Ethiopian capital, and the book of hymns he composed was approved for publication by church authorities as an initiative to attract the youth to worship. The first collection of the hymns, known as 


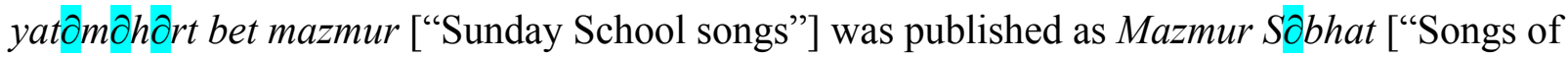
Praise"] in about 1971. Father Tsehai (Ethiopians are traditionally called by their first names) later became Director of the Education Training Department (1975-77), and, from 1979 to 1982, Director of the Youth Department at the Ethiopian Orthodox Church Patriarch's Office in Addis Ababa. He immigrated to the United States in 1982, and since 2001 has led Saint Michael's Ethiopian Orthodox Church in Mattapan, Mass.; Interviews with Tsehai Birhanu, 12 April 2008 and 17 September 2010.

95 Interview with Moges Seyoum, 2 August 2007.

${ }^{96}$ See Shelemay, "Toward an Ethnomusicology of the Early Music Movement” for a detailed discussion of the materials summarized here.

${ }^{97}$ Brown, "Pedantry or Liberation? A Sketch of the Historical Performance Movement," 30. ${ }^{98}$ Dreyfus, "Early Music Defended against Its Devotees," 307.

${ }^{99}$ The lively scholarly and academic arenas of the early music movement include journals such as Early Music History, published by Cambridge University Press since 1981, and early music degree and performance programs established at institutions across the United States and Europe. 100 The listening public for early music was certainly expanded by the impact of films such as Tous les matins $d u$ monde, which dramatized the story of composers Sainte Colombe and Marin Marais in late seventeenth-century France. The film soundtrack, released on CD, featured music by J.-B Lully, M. Marais, Sainte Colombe, F. Couperin, and J. Savali.

${ }^{101}$ Ziporyn, “One Man’s Traffic Noise.” Ziporyn has subsequently undertaken a lifelong involvement with Balinese music as a performer and composer. His opera, A House in Bali, was premiered in the U.S. and Bali during 2009-10.

102 Slobin, Subcultural Sounds, 98.

103 Ibid., 56.

${ }^{104}$ Ironically, Ethiopian restaurants (many featuring live musical performances as well) have attracted many beyond the boundaries of Ethiopian immigrants abroad. Cuisine has "proved to be an economic engine and identity marker of the diaspora community . . Ethiopian restaurants have become a ubiquitous part of cosmopolitan urban landscapes ... "; McCann, "Response: Doro Fänta," 385.

105 See Shelemay, "Ethiopian Musical Invention in Diaspora," 311. 
${ }^{106}$ Aweke's first international release, Aster (1989) was performed in Amharic, but incorporated multiple styles including traditional Ethiopian ballads, newly composed Ethiopian art songs performed with piano accompaniment, and songs that fused Ethiopian melodies with influences from rhythm and blues, jazz, and soul.

${ }^{107}$ See Jim Jarmusch's film Broken Flowers (2005). A great deal of Ethiopian music has circulated internationally through the French record series éthiopiques which released vol. 1 of the series in 1997, and which in 2011 has its twenty-seventh CD in press. Most of the éthiopiques volumes were originally recorded and produced by Amha Eshete for Amha Record Label between 1969 and 1978; twelve of Mulatu Astatke's compositions and/or arrangements of traditional melodies from that period are included on éthiopiques, vol. 4, Ethio jazz \& musique instrumentale, 1969-74, 1998. I thank Gilles Fruchaux of Buda Records for clarifying publication dates for the series in an email message dated 7 March 2011. For additional information about the music and career of Mulatu Astatke's (generally referred to as Mulatu, following the Ethiopian custom), see Shelemay, "Ethiopian Musical Invention in Diaspora," 306-9.

108 "Lent Time" is performed by Mulatu Astatke and ensemble in the BBC Film, Under African Skies: Ethiopia. "Dèwèl” (däwäl) is heard on éthiopiques, vol. 4, Ethio jazz \& musique instrumentale, 1969-74, track 14.

${ }^{109}$ Interview with Mulatu Astatke, 23 October 2007. See also Shelemay, "Ethiopian Musical Invention in Diaspora," 306-9.

110 The community types can be deployed on a continuum in any order. As will be discussed below, at some moments "musicking" can give rise to multiple collectivities at once, approaching the status of heterotopia, as discussed by Foucault and Miskowiec in "Of Other Spaces"; and by Soja in "Heterotopologies."

${ }^{111}$ It would also be possible to overlay each node of Figure 1 with its own intersecting axis, clarifying better if a given community privileges social dimensions of collectivity, as opposed to being more centered on musical elements. I thank an anonymous reader for a question that suggested this additional axis.

${ }^{112}$ An issue that has remained in the background throughout this essay relates to the size of a community. Turino encourages his students, in his monograph Music as Social Life, to partake of 
grassroots cultural cohorts; he suggests that "small is still beautiful," thus incorporating communities of varying sizes into his purview (227). Others presuppose the existence of a "critical mass" and buttress this perspective by citing a range of literature that seeks to show that size is important to the definition of community for a variety of strategic reasons. See Crossley, "Man Whose Web Expanded," 26.

${ }^{113}$ Here Fela Anikulapo Kuti (1938-1997) comes to mind as well, an individual who spawned communities of dissent and affinity. See Veal, Fela: The Life \& Times of an African Musical Icon. In the case of Fela, his status as an innovator of the popular Afro-Beat style preceded his later role as political activist and composer of protest songs, an interesting reversal of the relationship between dissent and affinity.

${ }^{114}$ The music of Tewodros Kassahun [sometimes spelled Kasahun], in particular his song "Yasteseryal" ("It Heals") from his 2005 CD of the same title, galvanized Ethiopians worldwide around political issues and subsequent tragic events related to the disputed 2005 Ethiopian elections. Teddy Afro's trial, conviction, and subsequent imprisonment on what were widely considered to be fabricated charges of a hit-and-run accident in Addis Ababa, and the publicity surrounding his release from prison in 2009, served only to increase his stature as a symbol of dissent. See Shelemay, "Music in the Ethiopian American Diaspora," 1162; and, for a broader perspective of the political context of Kassahun's imprisonment, see Lyons, “Transnational Politics in Ethiopia."

${ }^{115}$ Howard Rheingold writes: “ . . . the future of the Net is connected to the future of the community ..."”; Virtual Community, xxi.

${ }^{116}$ For a detailed overview of the role of communication technology in shaping cultural life, including musical networks, in Ethiopia and its diaspora, see Hafkin, “" 'Whatsupoch' on the Net: The Role of Information and Communication Technology in the Shaping of Transnational Ethiopian Identity."

${ }^{117}$ A case study of Balinese "alternapunk" music performance suggests that this type of duality is not uncommon; in the case of Balinese punk youth culture, musical and social processes move back and forth between inclusion and exclusion; Baulch, “Creating a Scene: Balinese Punk's Beginnings," 167.

${ }^{118}$ See Shelemay, "Ethiopian Musical Invention in Diaspora," 310-11. 
${ }^{119}$ See Slobin, Subcultural Sounds, 12-13, for a clear statement of what such a framework is not meant to be. But in seeking a more nuanced definition of community, this essay does dispute the position that the word homogenizes and naturalizes difference, implicitly incorporating a conservative political agenda, as suggested by Halberstam in "What's That Smell? Queer Temporalities and Subcultural Lives."

${ }^{120}$ For a recent case study of boundary delineation and maintenance through musical performance that includes examples of both enforced separation and incorporation, see Gidal, "Crossing and Purifying Boundaries: The Music of Umbanda and Quimbanda."

${ }^{121}$ See Müller and Störk, "Coptic Church," for details of the complex history of this relationship, which began in the fourth century and ended only in 1959 when an Ethiopian patriarch was named.

${ }^{122}$ See Gardner, "Portable Community," 157, for the suggestion that mobile and transient communities that unite around a mutual interest, in this case around bluegrass music and culture, emerged in response to difficulties of finding community in their permanent location and as part of a search "fill a void in their lives."

${ }^{123}$ Clifford, "Diasporas," 306-7. See also Turino, "Introduction. Identity and the Arts in Diaspora Communities." See also Hall, "Ethnography of Imagined Communities," in which she discusses the cultural processes that gave rise to nation formation among Sikh immigrants. ${ }^{124}$ See Cross, "Is Music the Most Important Thing We Ever Did?" For a summary of perspectives on music's role in evolution from neuroscience, see Patel, "Music, Biological Evolution, and the Brain"; also idem, Music, Language, and the Brain.

${ }^{125}$ Anshel and Kipper, "Influence of Group Singing on Trust and Cooperation"; and Kreutz et al., "Effects of Choir Singing or Listening." This study compared subjective and physiological responses produced by group singing with those elicited by listening to music, showing that amateur group singing leads to increases in both positive affect and production of proteins that defend against respiratory infections, suggesting a possible influence of musical behavior on well-being and health (632).

${ }^{126}$ These studies generally acknowledge the importance of synchronized movement to music as a universal aspect of human behavior and investigate culture-specific responses at different life stages and evaluate their impact. See Hannon and Trehub, "Tuning in to Musical Rhythms: 
Infants Learn More Readily than Adults"; Snyder et al., "Synchronization and Continuation Tapping to Complex Meters"; and Kirschner and Tomasello, "Joint Drumming: Social Context Facilitates Synchronization in Preschool Children.” Ethnomusicologists have begun to contribute actively to this inquiry; see Clayton, "Observing Entrainment in Music Performance: Videobased Observational Analysis of Indian Musicians’ Tanpura Playing and Beat Marking." See also Clayton, Sager. and Udo, "In Time with the Music: The Concept of Entrainment."

${ }^{127}$ Patel, "Music, Biological Evolution, and the Brain," 42.

${ }^{128}$ Clayton suggests that "it is important that musical entrainment studies consider how people actually behave in a variety of environments and contexts, as well as studying their performance in experimentally determined tasks; "Observing Entrainment," 28. The techniques of visual observation proposed by Clayton and his team provide insights into aspects of musical performance "that until now have gone largely unnoticed by performers, audiences, and musicologists alike ... Although the present study is not designed for the control of variables one would hope for in a laboratory experiment or computer simulation, the results may provide an illustration of the power of ethnomusicological studies to help direct psychological inquiry into productive new areas in the future"; ibid., 51. 